\title{
Mixed Ionic-Electronic Conductivity, Redox Behavior and Thermochemical Expansion of Mn-Substituted 5YSZ as an Interlayer Material for Reversible Solid Oxide Cells
}

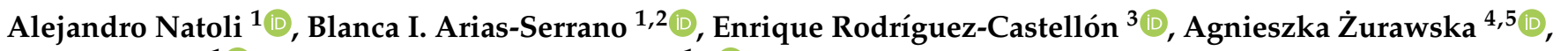 \\ Jorge R. Frade ${ }^{1}$ and Aleksey. A. Yaremchenko ${ }^{1, *(D)}$ \\ 1 CICECO-Aveiro Institute of Materials, Department of Materials and Ceramic Engineering, University of \\ Aveiro, 3810-193 Aveiro, Portugal; anatoli@ua.pt (A.N.); blanca@ua.pt (B.I.A.-S.); jfrade@ua.pt (J.R.F.) \\ 2 Leibniz Institute for Plasma Science and Technology, Felix-Hausdorff-Street 2, 17489 Greifswald, Germany \\ 3 Department of Inorganic Chemistry, Faculty of Science, University of Malaga, Campus de Teatinos, \\ 29071 Málaga, Spain; castellon@uma.es \\ 4 Institute of Power Engineering-Research Institute, Mory 8 Street, 01-330 Warsaw, Poland; \\ agnieszka.zurawska@ien.com.pl \\ 5 CTH2-Center for Hydrogen Technologies, Institute of Power Engineering, Augustówka 36 Street, \\ 02-981 Warsaw, Poland \\ * Correspondence: ayaremchenko@ua.pt
}

\section{check for}

updates

Citation: Natoli, A.; Arias-Serrano B.I.; Rodríguez-Castellón, E.;

Żurawska, A.; Frade, J.R.;

Yaremchenko, A.A. Mixed

Ionic-Electronic Conductivity, Redox Behavior and Thermochemical

Expansion of Mn-Substituted 5YSZ as an Interlayer Material for Reversible Solid Oxide Cells. Materials 2021, 14, 641. https://doi.org/10.3390/ ma14030641

Academic Editor: Enrico Negro

Received: 8 January 2021

Accepted: 25 January 2021

Published: 30 January 2021

Publisher's Note: MDPI stays neutral with regard to jurisdictional claims in published maps and institutional affiliations.

Copyright: (c) 2021 by the authors. Licensee MDPI, Basel, Switzerland. This article is an open access article distributed under the terms and conditions of the Creative Commons Attribution (CC BY) license (https:// creativecommons.org/licenses/by/ $4.0 /)$.
Abstract: Manganese-substituted 5 mol.\% yttria-stabilized zirconia (5YSZ) was explored as a prospective material for protective interlayers between electrolyte and oxygen electrodes in reversible solid oxide fuel/electrolysis cells. $\left[\left(\mathrm{ZrO}_{2}\right)_{0.95}\left(\mathrm{Y}_{2} \mathrm{O}_{3}\right)_{0.05}\right]_{1-x}\left[\mathrm{MnO}_{y}\right]_{x}(x=0.05,0.10$ and 0.15$)$ ceramics with cubic fluorite structure were sintered in air at $1600{ }^{\circ} \mathrm{C}$. The characterization included X-ray diffraction (XRD), scanning electron microscopy (SEM)/energy dispersive spectroscopy (EDS), X-ray photoelectron spectroscopy (XPS), thermogravimetry and dilatometry in controlled atmospheres, electrical conductivity measurements, and determination of oxygen-ion transference numbers by the electromotive force (EMF) technique. Mn-substituted 5YSZ solid solutions exhibit variable oxygen nonstoichiometry with manganese cations in a mixed $2+/ 3+$ oxidation state under oxidizing conditions. Substitution by manganese gradually increases the extent of oxygen content variation on thermal/redox cycling, chemical contribution to thermal expansion and dimensional changes on reduction. It also deteriorates oxygen-ionic conductivity and improves $p$-type electronic conductivity under oxidizing conditions, leading to a gradual transformation from predominantly ionic to prevailing electronic transport with increasing $x . \mathrm{Mn}^{2+/ 3+} \rightarrow \mathrm{Mn}^{2+}$ transformation under reducing atmospheres is accompanied by the suppression of electronic transport and an increase in ionic conductivity. All Mn-substituted 5YSZ ceramics are solid electrolytes under reducing conditions. Prolonged treatments in reducing atmospheres, however, promote microstructural changes at the surface of bulk ceramics and Mn exsolution. Mn-substituted 5YSZ with $0.05 \leq x<0.10$ is considered the most suitable for the interlayer application, due to the best combination of relevant factors, including oxygen content variations, levels of ionic/electronic conductivity and thermochemical expansion.

Keywords: solid oxide fuel cell; solid oxide electrolysis cell; zirconia; manganese oxide; ionic conductivity; thermochemical expansion; oxygen nonstoichiometry; mixed conductor; buffer layer

\section{Introduction}

Solid oxide cells (SOCs) are attractive high-temperature electrochemical systems that offer a solution for the efficient utilization of renewable energy. Solid oxide electrolysis cells (SOECs) can utilize excess electrical energy produced by renewable sources to generate green hydrogen as a fuel or energy storage, while solid oxide fuel cells (SOFCs) may convert chemical energy stored in $\mathrm{H}_{2}$ back into electricity with high conversion efficiency $[1,2]$. 
SOEC technology is based on the same main components and materials used in SOFCs, but is at a comparatively earlier development stage.

Long-term degradation remains a major obstacle to the introduction of this technology as a practical hydrogen production system. While some lifetime-limiting factors are common with SOFCs, and originate from high operation temperatures, a specific degradation mechanism in SOECs is related to electrolyte deterioration and delamination phenomena at or near electrolyte/anode interface [3-7]. Experimental and modeling results suggest that, under certain conditions, high oxygen pressures can develop in the electrolyte near the oxygen electrode/electrolyte interface (possibly resulting from insufficient electrochemical activity of the electrode materials for the oxygen evolution reaction) [6-9]. This oxygen pressure build-up may result in the formation of voids at the grain boundaries and intergranular fractures in the surface region of the solid electrolyte, delamination of the oxygen electrode, and the formation of cracks in the composite oxygen electrode [4-7]. All these factors contribute to the irreversible degradation of SOEC, including an increase in areaspecific ohmic/polarization resistance and mechanical failure. Cation interdiffusion was also reported to facilitate the degradation of electrode/electrolyte interface, particularly in the case of oxygen electrodes based on classic ( $\mathrm{La}, \mathrm{Sr}) \mathrm{MnO}_{3-\delta}(\mathrm{LSM})[10,11]$.

Solid oxide fuel/electrolysis cells tests $[3,12,13]$ demonstrated better tolerance to electrochemical degradation under reversible cycling rather than under continuous electrolysis, possibly by reversing contaminations or electrically driven cation de-mixing and chemical potential gradients across the cell components by orders of magnitude. This raises prospects to halt degradation on reverting from electrolysis to fuel cell mode, and to seek self-healing approaches based on reversible SOEC/SOFC cycles [13]. One possible approach may be based on the introduction of inclusions (in solid electrolyte) or a thin buffer interlayer with oxygen storage ability, preventing oxygen overpressure in electrolysis mode and reverting to oxygen loss in fuel cell mode.

The present work aims at the characterization of manganese- and yttria-co-substituted zirconia as a prospective interlayer material for reversible SOCs. Earlier reports demonstrated that the solubility of manganese oxide $\mathrm{MnO}_{y}$ in $\mathrm{ZrO}_{2}$ under oxidizing conditions is limited, $5.4 \mathrm{~mol} \%$ [14] or even lower [15] at $1400{ }^{\circ} \mathrm{C}$. Co-substitutions by $\mathrm{MnO}_{y}$ and yttria expand the solid solution formation field; the solubility limit of $\mathrm{Mn}$ in $\mathrm{ZrO}_{2}$ lattice increases with increasing temperature and $Y$ content [14,16-21]. Furthermore, the additions of $\mathrm{MnO}_{y}$ enable the stabilization of cubic fluorite structure at lower yttria contents compared to the binary $\mathrm{ZrO}_{2}-\mathrm{Y}_{2} \mathrm{O}_{3}$ system $[14,17,22]$. Hereafter, the conventional abbreviation $n$ YSZ is used to refer to $n$ mol.\% yttria-stabilized zirconia, e.g., $8 \mathrm{YSZ}$ corresponds to $\left(\mathrm{ZrO}_{2}\right)_{0.92}\left(\mathrm{Y}_{2} \mathrm{O}_{3}\right)_{0.08}$. Electrical studies reported in literature focused mainly on additions of manganese to 8YSZ [19-28], with only several publications on additions to 3YSZ [22,29]. Most reports agree that Mn additions (within the solid solubility limits) to 8YSZ result in a decrease in total electrical conductivity under oxidizing conditions, with an increase in activation energy $[20,21,23-28]$. This is accompanied by a gradual increase in $p$-type electronic contribution [22-24], although there is a substantial scattering in obtained oxygen-ion transference numbers: from $>0.99[20,21,23]$ to $\sim 0.2$ [24] for similar compositions under similar conditions. Small additions of manganese oxide to $3 \mathrm{YSZ}$ were also found to suppress electrical (ionic) conductivity [29], while 3YSZ, with 10-15 mol.\% of $\mathrm{MnO}_{y}$, were claimed to be predominantly electronic conductors [22]. Nonetheless, Mn-substituted 8YSZ was suggested as an intermediate layer between the electrolyte and the oxygen electrode in SOFC/SOEC $[21,30]$. In particular, the introduction of a 2 mol. $\% \mathrm{MnO}_{y}-8 \mathrm{YSZ}$ interlayer in a model SOEC was demonstrated to suppress the interfacial degradation and delamination of oxygen electrodes by inhibiting Mn diffusion from the LSM electrode into 8YSZ electrolyte [30].

The present work investigates the effect of manganese co-substitution on the properties of YSZ with a lower yttria content compared to conventional 8YSZ. The compositions were formulated as $\left[\left(\mathrm{ZrO}_{2}\right)_{0.95}\left(\mathrm{Y}_{2} \mathrm{O}_{3}\right)_{0.05}\right]_{1-x}\left[\mathrm{MnO}_{y}\right]_{x}$, with $x$ varying between 0.05 and 0.15. The cation ratios recalculated for the $\mathrm{AO}_{2}$ formula unit are listed in Table 1. Detailed 
characterization includes structural and microstructural studies, measurements of thermochemical expansion and electrical conductivity in controlled atmospheres, determination of ionic and electronic contributions to the total electrical transport, and assessment or redox behavior by thermogravimetry and conductivity relaxation experiments.

Table 1. Lattice parameters and density of as-prepared $\left[\left(\mathrm{ZrO}_{2}\right)_{0.95}\left(\mathrm{Y}_{2} \mathrm{O}_{3}\right)_{0.05}\right]_{1-x}\left[\mathrm{MnO}_{y}\right]_{x}$ ceramics.

\begin{tabular}{ccccc}
\hline $\boldsymbol{x}$ & Formula Unit & $\boldsymbol{a}, \AA^{\mathbf{1}}$ & Density, $\mathbf{g} / \mathbf{c m}^{\mathbf{3}}$ & $\begin{array}{c}\text { Relative } \\
\text { Density, } \mathbf{\%}^{\mathbf{2}}\end{array}$ \\
\hline 0.05 & $\mathrm{Zr}_{0.862} \mathrm{Y}_{0.091} \mathrm{Mn}_{0.048} \mathrm{O}_{2-\delta}$ & $5.11840(7)$ & 5.35 & 90 \\
0.10 & $\mathrm{Zr}_{0.818} \mathrm{Y}_{0.086} \mathrm{Mn}_{0.096} \mathrm{O}_{2-\delta}$ & $5.10632(5)$ & 5.36 & 91 \\
0.15 & $\mathrm{Zr}_{0.775} \mathrm{Y}_{0.082} \mathrm{Mn}_{0.144} \mathrm{O}_{2-\delta}$ & $5.09522(7)$ & 5.40 & 94 \\
\hline
\end{tabular}

${ }^{1}$ The uncertainties given in parentheses are the standard deviations in the refined parameters calculated by FullProf; ${ }^{2}$ Theoretical density was calculated taking into account oxygen content determined by thermogravimetric analysis (TGA).

\section{Materials and Methods}

Ceramic samples with composition $\left[\left(\mathrm{ZrO}_{2}\right)_{0.95}\left(\mathrm{Y}_{2} \mathrm{O}_{3}\right)_{0.05}\right]_{1-x}\left[\mathrm{MnO}_{\mathrm{y}}\right]_{x}(x=0.05,0.10$ and 0.15 ) were prepared by a solid-state synthesis route employing 5 mol.\% yttria partially stabilized zirconia $\left(\mathrm{ZrO}_{2}\right)_{0.95}\left(\mathrm{Y}_{2} \mathrm{O}_{3}\right)_{0.05}$ (Innovnano, Portugal, $\mathrm{d}_{50}=500 \mathrm{~nm}$ ) and manganese (IV) oxide $\mathrm{MnO}_{2}$ (Alfa Aesar, ThermoFisher, Kandel, Germany, 99.9\% purity, 325 mesh powder, particles agglomerates $\leq 10 \mu \mathrm{m}$ ) as starting reagents. The reagent powders were weighed and mixed in appropriate proportions and then balled-milled with ethanol for $4 \mathrm{~h}$ at $150 \mathrm{rpm}$ (Retsch S1 planetary mill, nylon containers, Tosoh tetragonal zirconia milling media). After milling and drying, the powders were subjected to consecutive calcination steps in air at $800^{\circ} \mathrm{C}, 1000{ }^{\circ} \mathrm{C}$, and three times at $1200^{\circ} \mathrm{C}, 5 \mathrm{~h}$ each step, with intermediate regrinding. Furthermore, after repeated ball-milling, the powders were compacted into disk-shaped samples ( $\$ 18 \mathrm{~mm}$, thickness $\sim 1.5 \mathrm{~mm})$ by uniaxial pressing $(\mathrm{F}=10 \mathrm{kN})$ and sintered in air at $1600{ }^{\circ} \mathrm{C}$ for $10 \mathrm{~h}$. Sintering was done using alumina plates as supports covered with alumina cups; each sample was placed on a bed of powder, and also covered with a powder of identical cation composition to act as a buffer against possible hightemperature $\mathrm{MnO}_{y}$ losses [18,31].

Sintered ceramics samples were polished and cut into rectangular bars for electrical and dilatometric measurements. The density of prepared ceramics was calculated from the geometric dimensions and mass of polished samples. Powdered samples for X-ray diffraction (XRD), X-ray photoelectron spectroscopy (XPS) and thermogravimetric analysis (TGA) studies were prepared by grinding sintered ceramics in a mortar.

XRD patterns were recorded at room temperature using a PANalytical $X^{\prime}$ Pert PRO MRD diffractometer $\left(\mathrm{CuK}_{\alpha}\right.$ radiation, PANalytical, Almelo, Netherlands) in $2 \Theta$ range of $20-80^{\circ}$ for phase analysis and $10-120^{\circ}$ for lattice parameter calculations. Unit cell parameters were refined in FullProf software (profile matching method, WinPLOTR version Sept. 2018, CDIFX UMR6226 Rennes, ILL Grenoble, France). Microstructural characterization was performed by scanning electron microscopy (SEM, Hitachi SU-70, Tokyo, Japan) coupled with energy dispersive spectroscopy (EDS, Bruker Quantax 400 detector, Berlin, Germany). XPS studies were performed on a PHI Versa Probe II spectrometer (Physical Electronics, Minneapolis, MN, USA) with monochromatic X-ray Al $\mathrm{K}_{\alpha}$ radiation (100 $\mu \mathrm{m}, 100 \mathrm{~W}, 20 \mathrm{kV}, 1486.6 \mathrm{eV})$ and a dual-beam charge neutralizer. The instrument work function of the spectrometer was calibrated using $\mathrm{Cu} \mathrm{2} p_{3 / 2}(932.7 \mathrm{eV}), \mathrm{Ag} 3 d_{5 / 2}(368.2$ $\mathrm{eV})$ and $\mathrm{Au} 4 f_{7 / 2}(84.0 \mathrm{eV})$ photoelectron lines. The collected XPS spectra were analyzed using PHI SmartSoft software (version 9.6.0, PHI, Minneapolis, MN, USA) and processed with MultiPak. Charge referencing was done against the adventitious carbon $\mathrm{C} 1 \mathrm{~s}$ signal $(284.8 \mathrm{eV})$. Recorded spectra were fitted using Gauss-Lorentz curves.

Dilatometric measurements were done at $25-1100{ }^{\circ} \mathrm{C}$ using a vertical Linseis L75 instrument in flowing air or $10 \% \mathrm{H}_{2}-\mathrm{N}_{2}$ gas mixture with a constant heating/cooling rate of $3{ }^{\circ} \mathrm{C} / \mathrm{min}$. TGA was performed at $25-1100{ }^{\circ} \mathrm{C}$ using Setaram Setsys $16 / 18$ instrument 
(sensitivity $0.4 \mu \mathrm{g}$, alumina crucibles, initial sample weight $\sim 0.54 \mathrm{~g}$ ) on heating/cooling at $2{ }^{\circ} \mathrm{C} / \mathrm{min}$ in flowing air or $10 \% \mathrm{H}_{2}-\mathrm{N}_{2}$ gas mixture or isothermally as a function of time on cycling between oxidizing and reducing atmospheres. All thermogravimetric data were corrected for buoyancy effects by subtracting the corresponding baselines recorded under identical conditions using dense inert ceramic samples of a similar volume.

Total electrical conductivity $(\sigma)$ was measured employing AC impedance spectroscopy (Keysight E4284A precision LCR meter, Santa Rosa, CA, USA, frequency range $20 \mathrm{~Hz}-2 \mathrm{MHz}$ ) and disk- or bar-shaped ceramic samples with applied porous Pt electrodes (Heraeus CL-11-5349 platinum paste, Hanau, Germany). The measurements were done in air in the temperature range of $500-1000{ }^{\circ} \mathrm{C}$ or isothermally at $700-900{ }^{\circ} \mathrm{C}$ as function of oxygen partial pressure using flowing $\mathrm{O}_{2}+\mathrm{N}_{2}$ and $\mathrm{H}_{2}+\mathrm{H}_{2} \mathrm{O}+\mathrm{N}_{2}$ gas mixtures. The average oxygen-ion transference numbers $\left(\overline{\mathrm{t}_{\mathrm{O}}}\right)$ under air $/ \mathrm{O}_{2}$ and air $/\left(10 \% \mathrm{H}_{2}-\mathrm{N}_{2}\right)$ gradients were determined at $700-900{ }^{\circ} \mathrm{C}$ by the electromotive force (EMF) technique modified to take the electrode polarization into account (Gorelov's modification) (see References [32-34] for details). Only gas-tight samples were used for the EMF measurements. The samples were hermetically sealed onto yttria-stabilized zirconia (YSZ) tubular measuring cell using G018-281 glass (Schott AG, Mainz, Germany) in a form of tape-casted glass rings and a glass paste (a mixture of glass powder with terpineol and ethyl cellulose).

In all experiments, the flow rates of gases were controlled using Bronkhorst massflow controllers (Ruurlo, The Netherlands). The oxygen partial pressure $\mathrm{p}\left(\mathrm{O}_{2}\right)$ in the gas mixtures was monitored by YSZ solid-electrolyte sensors (homemade, YSZ tubes from Tosoh, Tokyo, Japan). The representative $\mathrm{p}\left(\mathrm{O}_{2}\right)$ value in the $10 \% \mathrm{H}_{2}-\mathrm{N}_{2}$ gas mixture corresponded to $\sim 10^{-21}$ atm at $900{ }^{\circ} \mathrm{C}$. Note that $\mathrm{p}\left(\mathrm{O}_{2}\right)$ in this kind of gas mixtures is defined by the $\mathrm{p}\left(\mathrm{H}_{2} \mathrm{O}\right) / \mathrm{p}\left(\mathrm{H}_{2}\right)$ ratio and by the temperature-dependent equilibrium constant of hydrogen oxidation reaction, and therefore varies with temperature.

\section{Results}

\subsection{Phase Composition and Crystal Structure}

XRD analysis confirmed that $\left(\mathrm{ZrO}_{2}\right)_{0.95}\left(\mathrm{Y}_{2} \mathrm{O}_{3}\right)_{0.05}$, either as-delivered powder used for synthesis or ceramic samples sintered in air at $1600{ }^{\circ} \mathrm{C}$ for $10 \mathrm{~h}$, is partially-stabilized zirconia with tetragonal structure and a minor fraction of monoclinic phase. Additions of manganese oxide resulted in the stabilization of the fluorite cubic structure (space group $F m \overline{3} m)$. All prepared $\left[\left(\mathrm{ZrO}_{2}\right)_{0.95}\left(\mathrm{Y}_{2} \mathrm{O}_{3}\right)_{0.05}\right]_{1-x}\left[\mathrm{MnO}_{y}\right]_{x}(x=0.05,0.10$ and 0.15$)$ ceramics were single-phase, with no evidence of impurity phases detectable by XRD. An example of XRD pattern of as-prepared ceramics is given in Figure $1 \mathrm{~A}$.

Polished as-prepared ceramic samples were further inspected by SEM/EDS. Microscopic studies revealed the presence of occasional isolated inclusions of $\mathrm{MnO}_{y}$ with sizes $\leq 2 \mu \mathrm{m}$, mainly in the $x=0.15$ samples (Figure 2 ). The concentration of inclusions was low ( $<0.2$ vol. \% for $x=0.15$, as roughly estimated from the SEM images), so that its influence on the properties studied in this manuscript is considered negligible.

The analysis of available literature data suggests that the solubility of manganese oxide in $(\mathrm{Zr}, \mathrm{Y}) \mathrm{O}_{2-\delta}$ is limited, but varies with yttrium content and temperature. In particular, the equilibrium solubility limits of $\mathrm{MnO}_{y}$ at $1400{ }^{\circ} \mathrm{C}$ in air were reported to be $7.6,10.3$ and 11-12 mol.\% in 3, 6 and 8 mol.\% yttria-substituted zirconia, respectively [14,17-19]. Increasing temperature extends the solubility of $\mathrm{MnO}_{y}$ in $\left(\mathrm{ZrO}_{2}\right)_{0.92}\left(\mathrm{Y}_{2} \mathrm{O}_{3}\right)_{0.08}$ from $~ 5$ mol.\% at $1000{ }^{\circ} \mathrm{C}$ to $15-18 \mathrm{~mol} \%$ at $1500{ }^{\circ} \mathrm{C}[19,21]$. Thus, it can be assumed that the manganese contents in fluorite-type ceramics prepared in the present work, particularly in samples with $x=0.15$, are not equilibrium, but quenched from sintering temperature. This is also supported by the previous results on the processing of the $x=0.15$ ceramics at $1400-1600{ }^{\circ} \mathrm{C}[35]$, showing that the concentration and size of $\mathrm{MnO}_{y}$ precipitates increase with a reduction in time and the temperature of firing.

The lattice parameter of as-prepared fluorite-type solid solutions decreases linearly with increasing manganese content (Table 1 and Figure 3). The ionic radius of zirconium cations in an 8-fold coordination in the cubic fluorite lattice is $0.84 \AA$ [36]. Thus, a de- 
crease in the lattice parameter with $x$ can reasonably be attributed to the incorporation of manganese cations in a lower coordination $\left(r^{\mathrm{VI}}\left(\mathrm{Mn}_{\mathrm{LS}}^{3+}\right)=0.58 \AA, r^{\mathrm{VI}}\left(\mathrm{Mn}_{H S}^{3+}\right)=0.65 \AA\right.$ or $\left.r^{\mathrm{VI}}\left(\mathrm{Mn}_{\mathrm{LS}}^{2+}\right)=0.67 \AA[36]\right)$ into the zirconia lattice combined with a simultaneous moderate decrease in the concentration of large yttrium cations $\left(r^{\mathrm{VIII}}\left(\mathrm{Y}^{3+}\right)=1.02 \AA[36]\right)$.

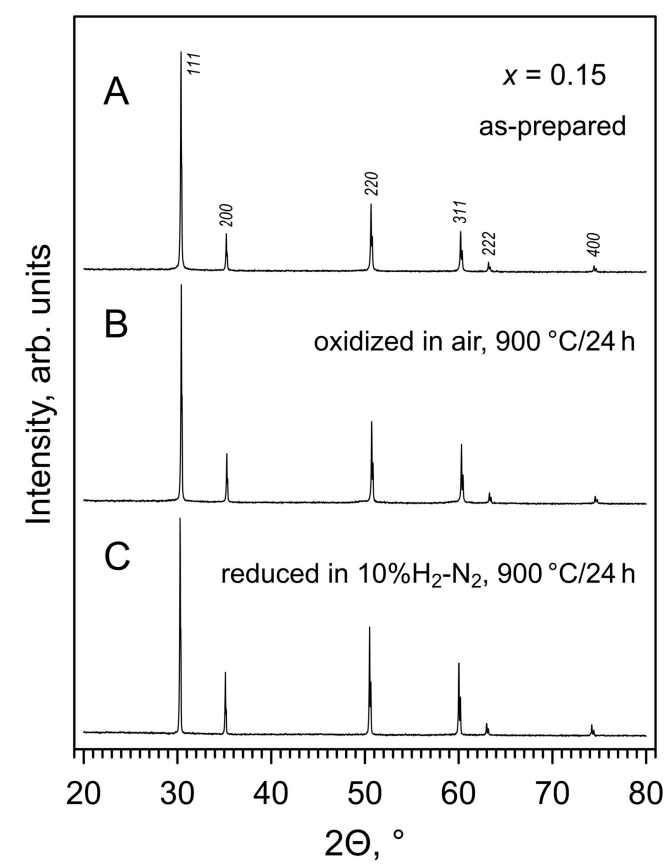

Figure 1. X-ray diffraction $(\mathrm{XRD})$ patterns of crashed $\left[\left(\mathrm{ZrO}_{2}\right)_{0.95}\left(\mathrm{Y}_{2} \mathrm{O}_{3}\right)_{0.05}\right]_{0.85}\left[\mathrm{MnO}_{y}\right]_{0.15}$ ceramics: (A) as-prepared; (B) oxidized in air at $900{ }^{\circ} \mathrm{C}$ for $24 \mathrm{~h}$; and (C) reduced in $10 \% \mathrm{H}_{2}-\mathrm{N}_{2}$ flow at $900{ }^{\circ} \mathrm{C}$ for $24 \mathrm{~h}$. XRD reflections are indexed in the space group $F m \overline{3} m$.
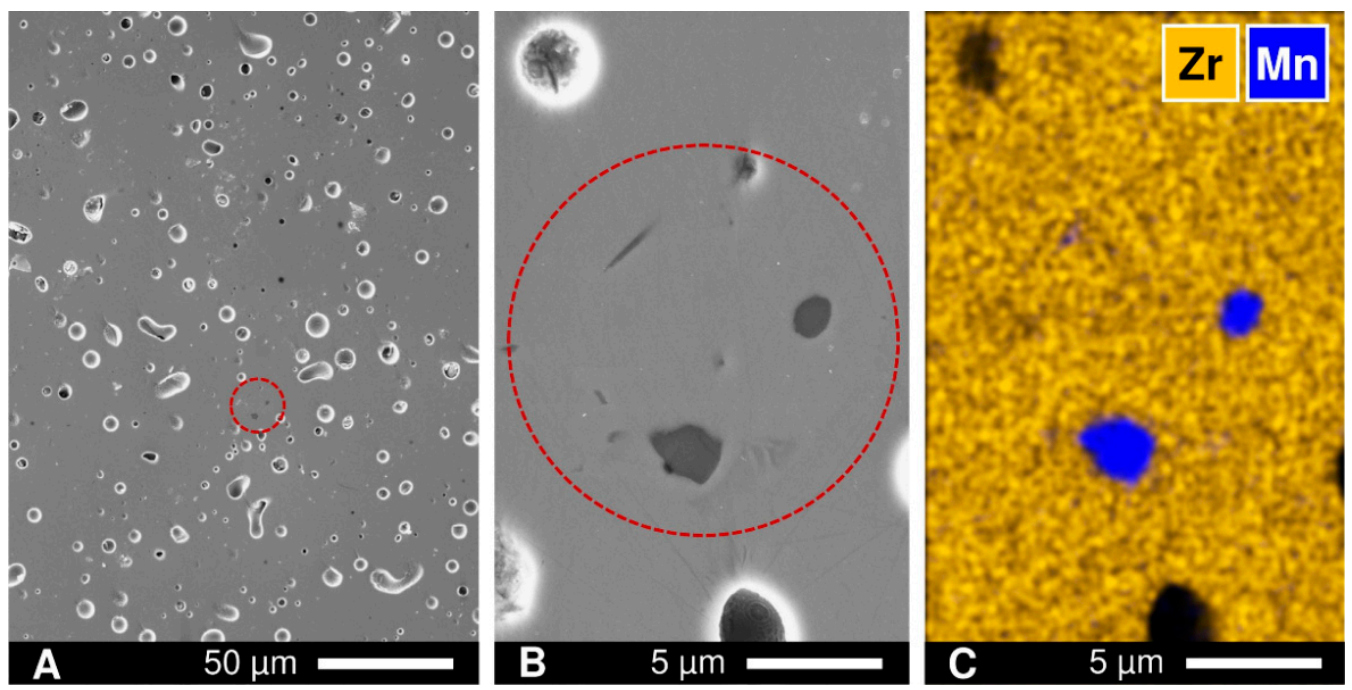

Figure 2. (A) Scanning electron microscopy (SEM) image of polished as-prepared $\left[\left(\mathrm{ZrO}_{2}\right)_{0.95}\left(\mathrm{Y}_{2} \mathrm{O}_{3}\right)_{0.05}\right]_{0.85}\left[\mathrm{MnO}_{y}\right]_{0.15}$ ceramics; (B) magnified image of selected area; and (C) corresponding energy dispersive spectroscopy (EDS) elemental mapping. 


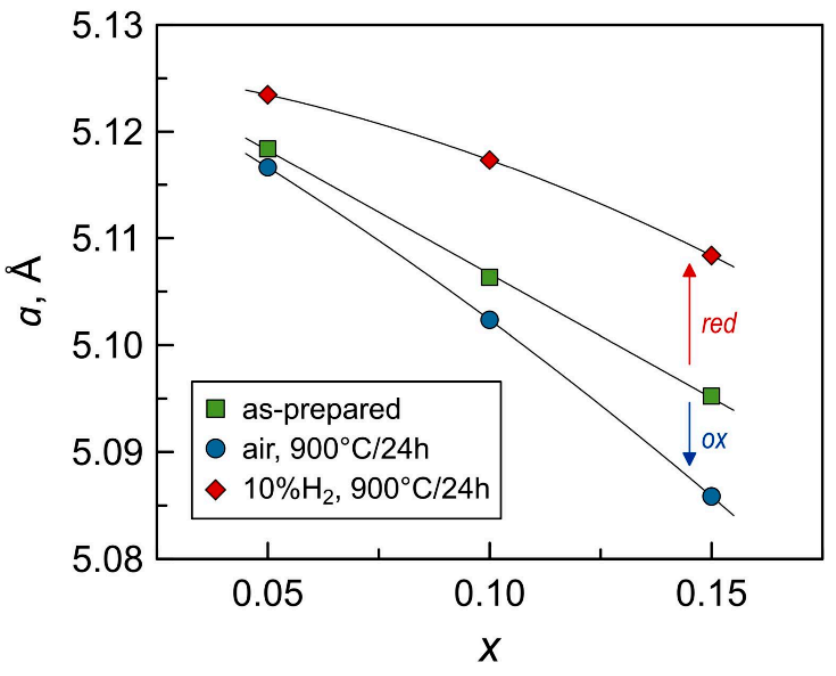

Figure 3. Lattice parameters of fluorite $\left[\left(\mathrm{ZrO}_{2}\right)_{0.95}\left(\mathrm{Y}_{2} \mathrm{O}_{3}\right)_{0.05}\right]_{1-x}\left[\mathrm{MnO}_{y}\right]_{x}$ solid solutions as function of manganese content: as prepared, after oxidation in air at $900{ }^{\circ} \mathrm{C}$ for $24 \mathrm{~h}$, and after reduction in $10 \% \mathrm{H}_{2}-\mathrm{N}_{2}$ flow at $900{ }^{\circ} \mathrm{C}$ for $24 \mathrm{~h}$.

The density of prepared ceramics was $90-94 \%$ of theoretical (Table 1). The grain size was in the range of $2-20 \mu \mathrm{m}$ for $x=0.05$ and 3-80 $\mu \mathrm{m}$ for $x=0.10-0.15$. Additions of manganese resulted in some improvement in sinterability and grain growth, in agreement with literature reports $[28,37,38]$, probably due to the relatively high diffusivity of $\mathrm{Mn}$ species in cubic zirconia [39].

\subsection{Mn Oxidation State and Oxygen Nonstoichiometry in Air}

The XPS spectra were collected on as-sintered crashed ceramic samples. The binding energy (BE) values of the $\mathrm{Zr} 3 d_{3 / 2}$ and $\mathrm{Y} 3 d_{3 / 2}$ signals were found at 158.4-158.6 and 183.8 $-184.0 \mathrm{eV}$, respectively, in agreement with the literature data on cubic and tetragonal YSZ [40] and Mn-doped YSZ systems [41,42]. The Mn $2 p$ core-level spectra for all compositions are shown in Figure 4A; the corresponding BE values are listed in Table 2. The BEs of the Mn $2 p_{1 / 2}$ and Mn $2 p_{3 / 2}$ signals are given by the positions of the maxima of the main peaks. The asymmetric Mn $2 p_{3 / 2}$ main peak is located at $641.0-641.4 \mathrm{eV}$ with a $2 p_{3 / 2}-2 p_{1 / 2}$ splitting of 11.7-12.0 eV. These values are closer to the $\mathrm{BE}$ of Mn 2 $p_{3 / 2}$ peaks reported for $\mathrm{MnO}(640.6 \mathrm{eV}), \mathrm{Mn}_{3} \mathrm{O}_{4}(641.4 \mathrm{eV})$ and $\mathrm{Mn}_{2} \mathrm{O}_{3}(641.9 \mathrm{eV})$ binary oxides rather than for $\mathrm{MnO}_{2}(642.2 \mathrm{eV})$ [43]. Therefore, Mn cations in 2+ and 3+ oxidation states are expected to prevail for all compositions, although a minor presence of $\mathrm{Mn}^{4+}$ ions cannot be discarded based on the obtained XPS data. In addition, a satellite peak at a BE of $\sim 647 \mathrm{eV}$ (full width at half maximum $(\mathrm{FWHM})=3.5 \mathrm{eV}$ ) was evidenced in all the Mn $2 p$ spectra (Figure 4A). This feature is characteristic of $\mathrm{MnO}$ [44] and has not been reported for neither $\mathrm{Mn}_{2} \mathrm{O}_{3}$ nor $\mathrm{MnO}_{2}$, thus further suggesting the presence of $\mathrm{Mn}^{2+}$ species in the samples. A slightly higher intensity of this satellite feature for $x=0.05$ seems to imply a lower average oxidation state of $\mathrm{Mn}$ in this sample. A minor decrease in FWHM of the Mn2 $p_{3 / 2}$ peak from $3.3 \mathrm{eV}(x=0.05)$ to $3.0-3.1 \mathrm{eV}(x=0.10$ and 0.15$)$ is also likely to be related to a lower concentration of $\mathrm{Mn}^{2+}$ in the samples with a higher Mn content. 

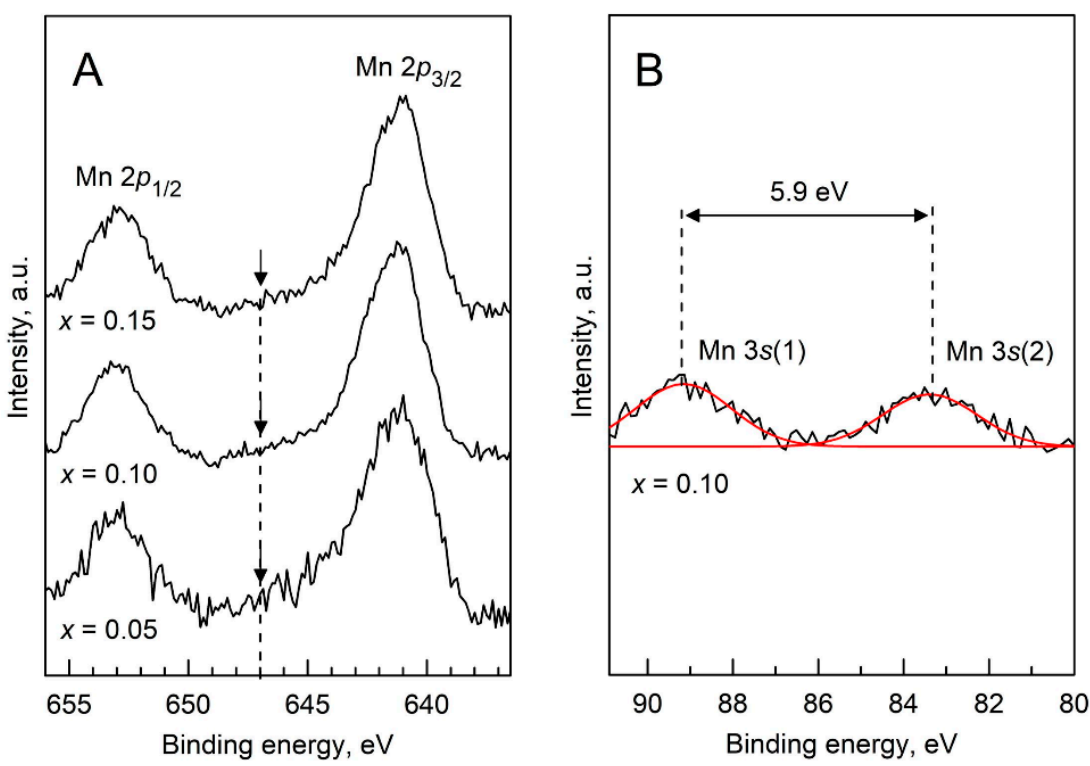

Figure 4. (A) X-ray photoelectron spectroscopy (XPS) spectra of $\left[\left(\mathrm{ZrO}_{2}\right)_{0.95}\left(\mathrm{Y}_{2} \mathrm{O}_{3}\right)_{0.05}\right]_{1-x}\left[\mathrm{MnO}_{y}\right]_{x}$ ceramics in the Mn $2 p$ core level region; and (B) Representative fitting of the Mn $3 s$ multiplet for the $x=0.10$ sample. The arrows in (A) indicate the position of a satellite peak at a binding energy (BE) of $\sim 647 \mathrm{eV}$. The spectra are shown with a subtracted background.

Table 2. Binding energies (eV) for Mn 2p and Mn 3s core level components of XPS spectra of as-prepared Mn-substituted 5YSZ.

\begin{tabular}{|c|c|c|c|c|c|c|c|}
\hline \multirow{2}{*}{$x$} & \multicolumn{4}{|c|}{$\operatorname{Mn} 2 p$} & \multicolumn{3}{|c|}{$\mathrm{Mn} 3 s$} \\
\hline & $2 p_{1 / 2}$ & $2 p_{3 / 2}$ & FWHM $\left(2 p_{3 / 2}\right)^{1}$ & $\Delta\left(2 p_{3 / 2}-2 p_{1 / 2}\right)$ & $3 s(1)$ & $3 s(2)$ & $\Delta(3 s(2)-3 s(1))$ \\
\hline 0.05 & 653.0 & 641.0 & 3.31 & 12.0 & 82.7 & 89.3 & 6.4 \\
\hline 0.10 & 653.1 & 641.4 & 3.10 & 11.7 & 83.4 & 89.2 & 5.9 \\
\hline 0.15 & 652.9 & 641.2 & 3.03 & 11.7 & 83.1 & 89.2 & 6.1 \\
\hline
\end{tabular}

${ }^{1}$ Full width at half maximum (FWHM) was obtained assuming a single contribution to the Mn $2 p_{3 / 2}$ component.

Analysis of the Mn $3 s$ core level spectrum is more useful to assess the oxidation state of Mn. A representative fitting of the Mn $3 s$ multiplet for the sample with $x=0.10$ is included in Figure 4B. The spectra exhibited two components with the splitting magnitude being related to the oxidation state of the $\mathrm{Mn}$ ions: typically $6.5-5.7 \mathrm{eV}$ for $\mathrm{Mn}^{2+}$ in $\mathrm{MnO}$, 5.5-5.2 eV for $\mathrm{Mn}^{3+}$ in $\mathrm{Mn}_{2} \mathrm{O}_{3}$, and 4.7-4.5 eV for $\mathrm{Mn}^{4+}$ in $\mathrm{MnO}_{2}$ [45,46]. The measured $\Delta(3 s(2)-3 s(1))$ values (Table 2$)$ ranged from $6.4 \mathrm{eV}(x=0.05)$ to $5.9 \mathrm{eV}(x=0.10)$, thereby supporting a mean Mn oxidation state lower than $3+$ in all the samples, as well as a higher concentration of $\mathrm{Mn}^{2+}$ species in the $x=0.05$ sample.

TGA was employed to determine the absolute values of oxygen nonstoichiometry and average manganese oxidation state in Mn-substituted 5YSZ in air (Figure 5). The TGA data were obtained on temperature cycling in air followed by the isothermal reduction of the samples in $10 \% \mathrm{H}_{2}-\mathrm{N}_{2}$ flow at $900{ }^{\circ} \mathrm{C}$ until constant weight (see discussion below). The calculations were done assuming that all manganese in reduced samples is in a 2+ oxidation state. This assumption is consistent with redox changes in the Mn-O system [47], and also with the evidence by electron paramagnetic resonance (EPR) studies of manganese-doped zirconia [48] and YSZ [49,50], and the results of thermodynamic modeling of the Zr-Y-Mn-O system [51]. 

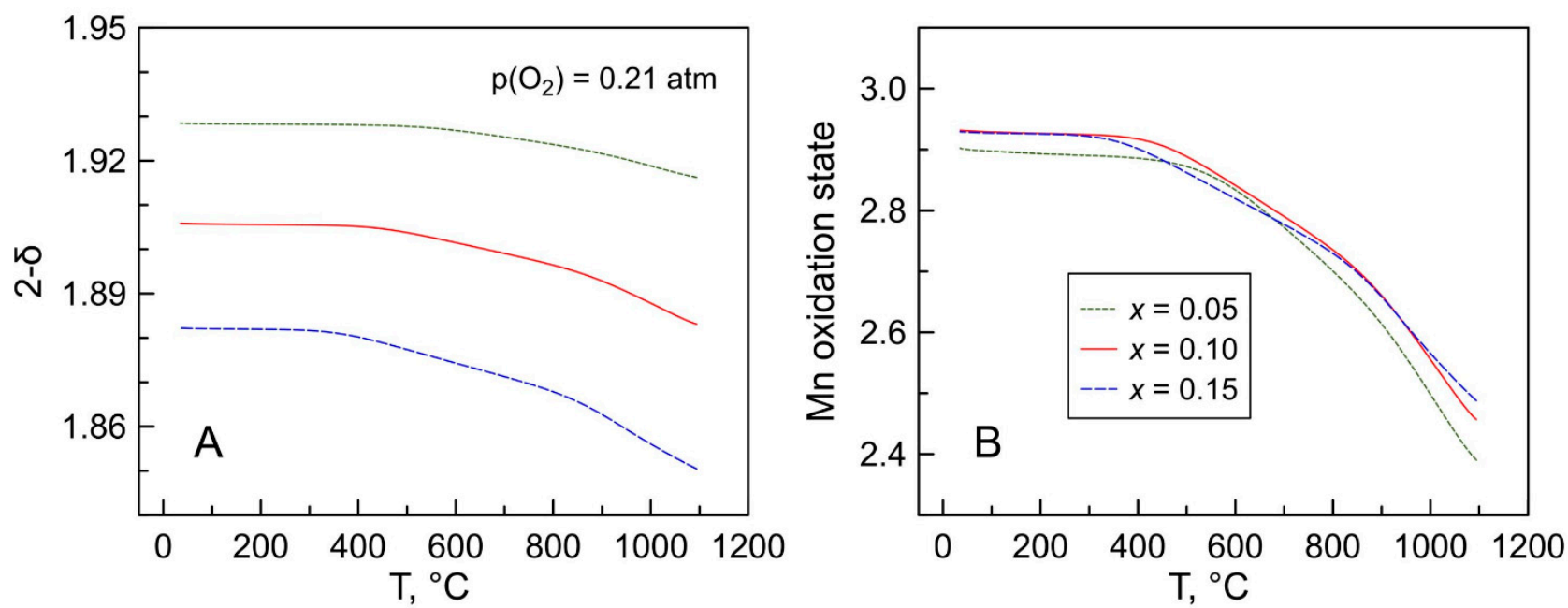

Figure 5. Temperature dependence of: (A) oxygen nonstoichiometry per $\mathrm{Zr}_{1-a-b} \mathrm{Y}_{a} \mathrm{Mn}_{b} \mathrm{O}_{2-\delta}$ formula unit; and (B) average Mn oxidation state in $\left[\left(\mathrm{ZrO}_{2}\right)_{0.95}\left(\mathrm{Y}_{2} \mathrm{O}_{3}\right)_{0.05}\right]_{1-x}\left[\mathrm{MnO}_{y}\right]_{x}$ ceramics in air calculated from the TGA data (cooling regime).

The TGA results demonstrated that Mn-substituted 5YSZ ceramics exhibit variable oxygen content on temperature cycling in air above $300-500{ }^{\circ} \mathrm{C}$ (depending on composition) associated with reversible reduction/oxidation of manganese cations

$$
\mathrm{Mn}^{3+}+\frac{1}{2} \mathrm{O}^{2-} \underset{\mathrm{T} \downarrow}{\stackrel{\mathrm{T} \uparrow}{\rightleftarrows}} \mathrm{Mn}^{2+}+\frac{1}{4} \mathrm{O}_{2}
$$

or, using Kroger-Vink notation:

$$
\mathrm{Mn}_{\mathrm{Zr}}^{\prime}+\frac{1}{2} \mathrm{O}_{\mathrm{O}}^{\times} \underset{\mathrm{T} \downarrow}{\stackrel{\mathrm{T} \uparrow}{\rightleftarrows}} \mathrm{Mn}_{\mathrm{Zr}}^{\prime \prime}+\frac{1}{2} \mathrm{~V}_{\mathrm{O}}^{\bullet \bullet}+\frac{1}{4} \mathrm{O}_{2}
$$

The calculated average oxidation state of Mn cations in the studied materials in air is below 3+ (Figure 5B), in accordance with the XPS results. The mean Mn valence is nearly independent of the total manganese content varying in a narrow range 2.61-2.66 at $900{ }^{\circ} \mathrm{C}$ and $2.90-2.93$ after cooling down to room temperature, although the $x=0.05$ ceramics showed a tendency to a slightly higher relative fraction of $\mathrm{Mn}^{2+}$ compared to other compositions. These results are in excellent agreement with available literature reports, showing a mixed 2+/3+ oxidation state of manganese cation in Mn-doped YSZ. In particular, the results of EPR and optical absorption spectroscopy studies of 9.5YSZ single crystals containing impurity levels of $\mathrm{Mn}(\leq 0.1 \mathrm{wt} . \%)$ revealed that the fraction of bivalent manganese, $\left[\mathrm{Mn}^{2+}\right] /[\mathrm{Mn}]_{\text {total }}$, in the samples equilibrated with air at $800{ }^{\circ} \mathrm{C}$ is close to $45-50 \%[49,50,52,53]$. Mixed $\mathrm{Mn}^{2+/ 3+}$ oxidation state in manganese-doped 8YSZ ceramics was demonstrated by EPR [48] and XANES (X-ray Absorption Spectroscopy in the Near Edge region) [16] studies and supported by the thermodynamic modeling of this system [51]. Appel et al. [54] performed EELS (Electron Energy Loss Spectroscopy) studies of Mn-doped 7.5YSZ ceramics, and also concluded that Mn cations are in a mixed 2+/3+ state, and that the average $\mathrm{Mn}$ oxidation state does not change with manganese content in the studied compositional range (2-10 mol.\% of $\mathrm{MnO}_{y}$ ). The presence of $\mathrm{Mn}^{4+}$ in $\mathrm{Mn}$-doped YSZ was ruled out by EPR measurements, even under oxidizing conditions $[48,50]$.

The substitution of $\mathrm{Zr}^{4+}$ by lower-valence $\mathrm{Mn}^{3+/ 2+}$ generates oxygen vacancies in the fluorite lattice. The electroneutrality condition for Mn-substituted YSZ is given by

$$
2\left[\mathrm{Mn}_{\mathrm{Zr}}^{\prime \prime}\right]+\left[\mathrm{Mn}_{\mathrm{Zr}}^{\prime}\right]+\left[\mathrm{Y}_{\mathrm{Zr}}^{\prime}\right]=2\left[\mathrm{~V}_{\mathrm{O}}^{\bullet \bullet}\right]=2 \delta
$$


The increase in manganese content results in a gradual increase in the concentration of oxygen vacancies and also in the extent of oxygen nonstoichiometry variations with temperature (Figure 5A). A specific feature observed in the thermogravimetric curves, and therefore in temperature dependencies of calculated parameters, is a change in slope at $820-880{ }^{\circ} \mathrm{C}$, probably corresponding to a limiting range for partial relaxation of quenchedin conditions. The exact reason for this is under question; possible factors may include a change of limiting stage of redox re-equilibration process (surface exchange $\leftrightarrow$ bulk diffusion) or order-disorder processes in the fluorite lattice.

\subsection{Electrical Transport Properties under Oxidizing Conditions}

All prepared Mn-substituted 5YSZ ceramics exhibit semiconducting behavior: electrical conductivity increases on heating. As-prepared ceramic materials show a comparable level of conductivity in the high-temperature range in air (Figure 6). Increasing the $\mathrm{Mn}$ content from $x=0.05$ to $x=0.10$ results in a moderate reduction in $\sigma$, while further substitution results in an enhancement in electrical transport. At the same time, substitution by manganese is accompanied by a gradual decrease in the activation energy of electrical conductivity (Table 3). As a result, the electrical conductivity of the studied materials increases with the Mn concentration in the fluorite lattice at temperatures below $\sim 650{ }^{\circ} \mathrm{C}$.

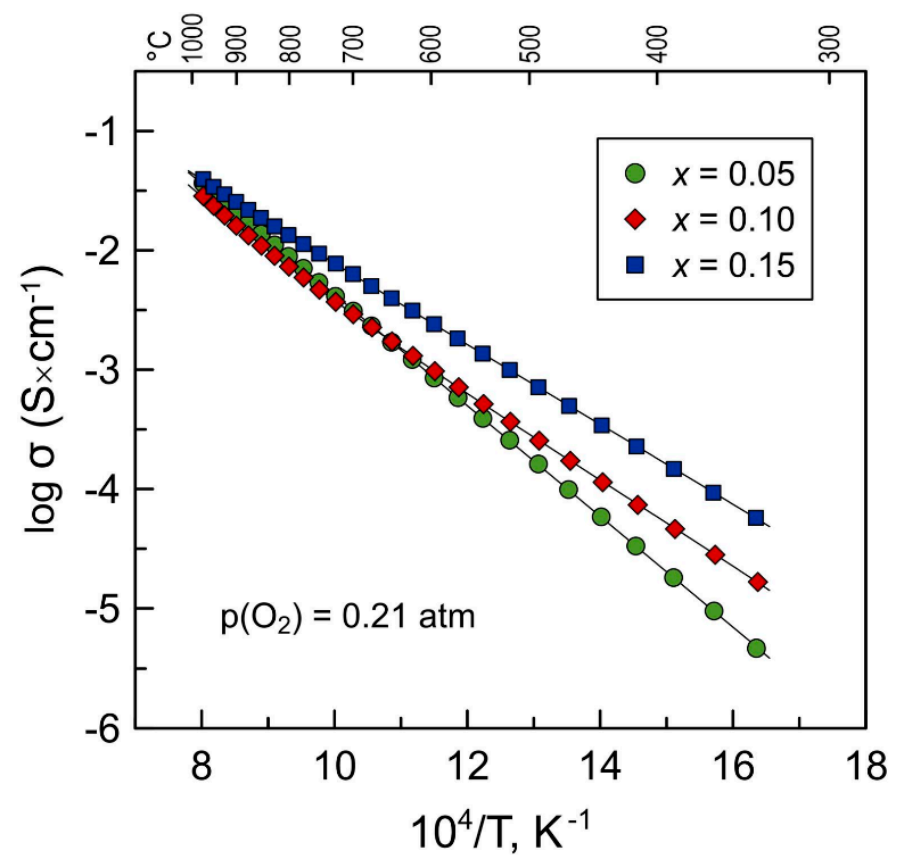

Figure 6. Temperature dependence of total electrical conductivity of as-prepared Mn-substituted $5 Y S Z$ ceramics in air.

Table 3. Parameters of Arrhenius model ${ }^{1}$ for the total electrical conductivity of as-prepared $\left[\left(\mathrm{ZrO}_{2}\right)_{0.95}\left(\mathrm{Y}_{2} \mathrm{O}_{3}\right)_{0.05}\right]_{1-x}\left[\mathrm{MnO}_{y}\right]_{x}$ ceramics in air $\left(340-970{ }^{\circ} \mathrm{C}\right)$.

\begin{tabular}{cccc}
\hline $\boldsymbol{x}$ & $\mathbf{E}_{\mathbf{A}}, \mathbf{k J} / \mathbf{m o l}$ & $\ln \left(\mathbf{A}_{\mathbf{0}}\right)$ & $\boldsymbol{\rho}^{\mathbf{2}}$ \\
\hline 0.05 & $96.1 \pm 0.2$ & $13.02 \pm 0.03$ & 0.99996 \\
0.10 & $80.8 \pm 0.7$ & $11.14 \pm 0.10$ & 0.9991 \\
0.15 & $72.2 \pm 0.3$ & $10.76 \pm 0.04$ & 0.9998 \\
\hline
\end{tabular}

${ }^{1} \sigma=\left(\mathrm{A}_{0} / \mathrm{T}\right) \exp \left(-\mathrm{E}_{\mathrm{A}} /(\mathrm{RT})\right) ;^{2} \rho$ is the correlation coefficient.

Isothermal electrical measurements at $900{ }^{\circ} \mathrm{C}$ revealed, however, that all the $\mathrm{Mn}$ substituted 5YSZ exhibited a quite slow relaxation of electrical conductivity with time under oxidizing conditions. This was observed even for as-prepared samples in atmospheric air: the conductivity of $x=0.10$ and $x=0.15$ samples tended to increase with time, while 
the sample with $x=0.05$ showed the opposite behavior (Figure 7A). Thermogravimetric studies showed that this is accompanied by a slow weight gain (i.e., oxygen uptake) for all compositions.
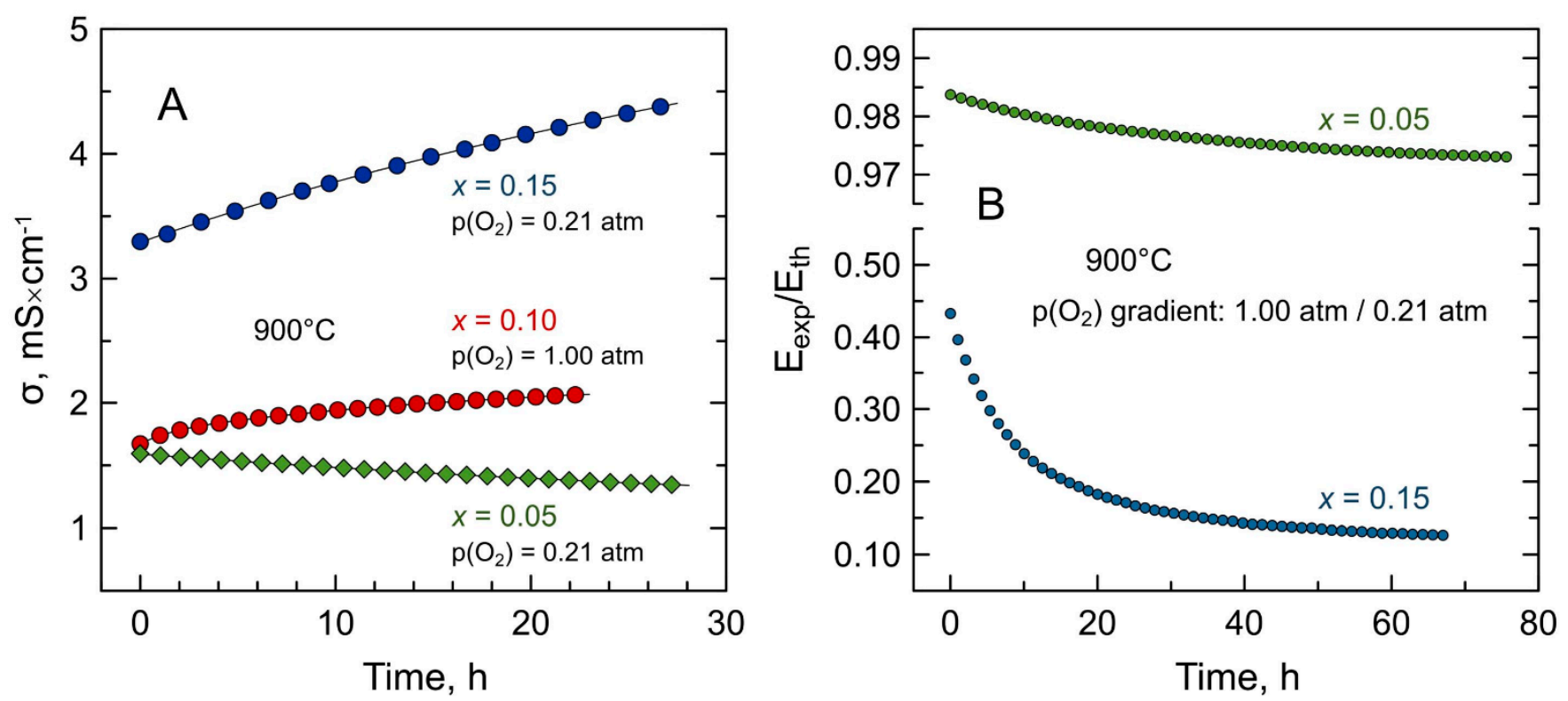

Figure 7. Examples of relaxation of: (A) electrical conductivity of as-prepared Mn-substituted 5YSZ ceramics under oxidizing conditions at $900{ }^{\circ} \mathrm{C}$; and (B) observed $\mathrm{E}_{\exp } / \mathrm{E}_{\text {th }}$ values of the samples in air $/ \mathrm{O}_{2}$ concentration cells at $900{ }^{\circ} \mathrm{C}$.

Since the Mn content in prepared materials at temperatures $\leq 1000^{\circ} \mathrm{C}$ is expected to be non-equilibrium (quenched from sintering conditions), a possible explanation for the slow transient processes occurring even in air at $900{ }^{\circ} \mathrm{C}$ could be very sluggish exsolution of the excess of $\mathrm{Mn}$ from the fluorite lattice; however, one could not find microstructural changes supporting this. No evidence of $\mathrm{Mn}$ segregation on the surface of polished samples was observed by SEM/EDS, even after prolonged annealing at $900{ }^{\circ} \mathrm{C}$ for $360 \mathrm{~h}$ (Figure 8). On the contrary, even a short treatment at the higher temperature, $1400{ }^{\circ} \mathrm{C}$, resulted in manganese exsolution from the bulk of ceramics and accumulation of $\mathrm{MnO}_{y}$ grains on the surface (Figure 8). This suggests that cation diffusivity and the phase re-equilibration at $\leq 900{ }^{\circ} \mathrm{C}$ are very slow, in agreement with some indications in literature [19], and are unlikely to be responsible for the observed relaxation processes.

The structural studies also do not support the possible exsolution of Mn. A significant decrease in manganese concentration in the fluorite lattice would result in a lattice expansion and the onset of a Mn-rich phase. On the contrary, it was found that while all materials remain single-phase solid solutions (Figure 1B), annealing in air at $900{ }^{\circ} \mathrm{C}$ results in a contraction of the fluorite unit cell (Figure 3). This implies that slow oxygen uptake at $900{ }^{\circ} \mathrm{C}$ is associated with $\mathrm{Mn}^{2+} \rightarrow \mathrm{Mn}^{3+}$ oxidation, and lattice shrinkage is caused by a corresponding decrease in the average size of manganese cations (e.g., $r^{\mathrm{VI}}\left(\mathrm{Mn}_{H S}^{3+}\right)=0.65 \AA$ and $\left.r^{\mathrm{VI}}\left(\mathrm{Mn}_{H S}^{2+}\right)=0.83 \AA[36]\right)$.

A slow relaxation process at $900{ }^{\circ} \mathrm{C}$ was also observed in the course of ionic transference numbers determination by the EMF method. Figure 7B illustrates the drift of $E_{\exp } / \mathrm{E}_{\text {th }}$ ratio with time for air $/ \mathrm{Pt} /(\mathrm{Mn}$-substituted $\mathrm{YSZ}) / \mathrm{Pt} / \mathrm{O}_{2}$ concentration cells. $\mathrm{E}_{\text {exp }}$ and $\mathrm{E}_{\text {th }}$ designate experimentally measured open-circuit voltage of the cell and theoretical voltage defined by the Nernst equation, respectively. In the classic EMF method, the $E_{\exp } / \mathrm{E}_{\text {th }}$ ratio gives an average ionic transference number in a given $\mathrm{p}\left(\mathrm{O}_{2}\right)$ range. Gorelov's modification of the EMF method $[32,55,56]$ was employed in the present work to account for the nonnegligible polarization of cell electrodes resulting in underestimation of ionic transference numbers. As shown in Figure $7 \mathrm{~B}, \mathrm{E}_{\mathrm{exp}} / \mathrm{E}_{\text {th }}$ values decreased slowly with time and required over $70 \mathrm{~h}$ at $900{ }^{\circ} \mathrm{C}$ to stabilize. The measured $\mathrm{E}_{\mathrm{exp}} / \mathrm{E}_{\text {th }}$ ratio and the average oxygen-ion 
transference numbers at the beginning of the experiment (immediately after sealing the sample at $950{ }^{\circ} \mathrm{C}$ and cooling down to $900{ }^{\circ} \mathrm{C}$ ) and after $\geq 70 \mathrm{~h}$ of sample equilibration are summarized in Table 4 . For all Mn-substituted 5YSZ ceramics, $\mathrm{E}_{\exp } / \mathrm{E}_{\text {th }}$ and $\overline{\mathrm{t}_{\mathrm{O}}}$ values decreased after the relaxation process implying a decline in ionic contribution and/or an enhancement of electronic contribution to total electrical transport. The extent of these changes is correlated with the nominal Mn concentration. In agreement with electrical conductivity measurements (Figure 7A), the ohmic resistance of the $x=0.05$ sample increased during the relaxation process, while $x=0.10$ and 0.15 samples exhibited a decrease in resistance with time (Table 4).
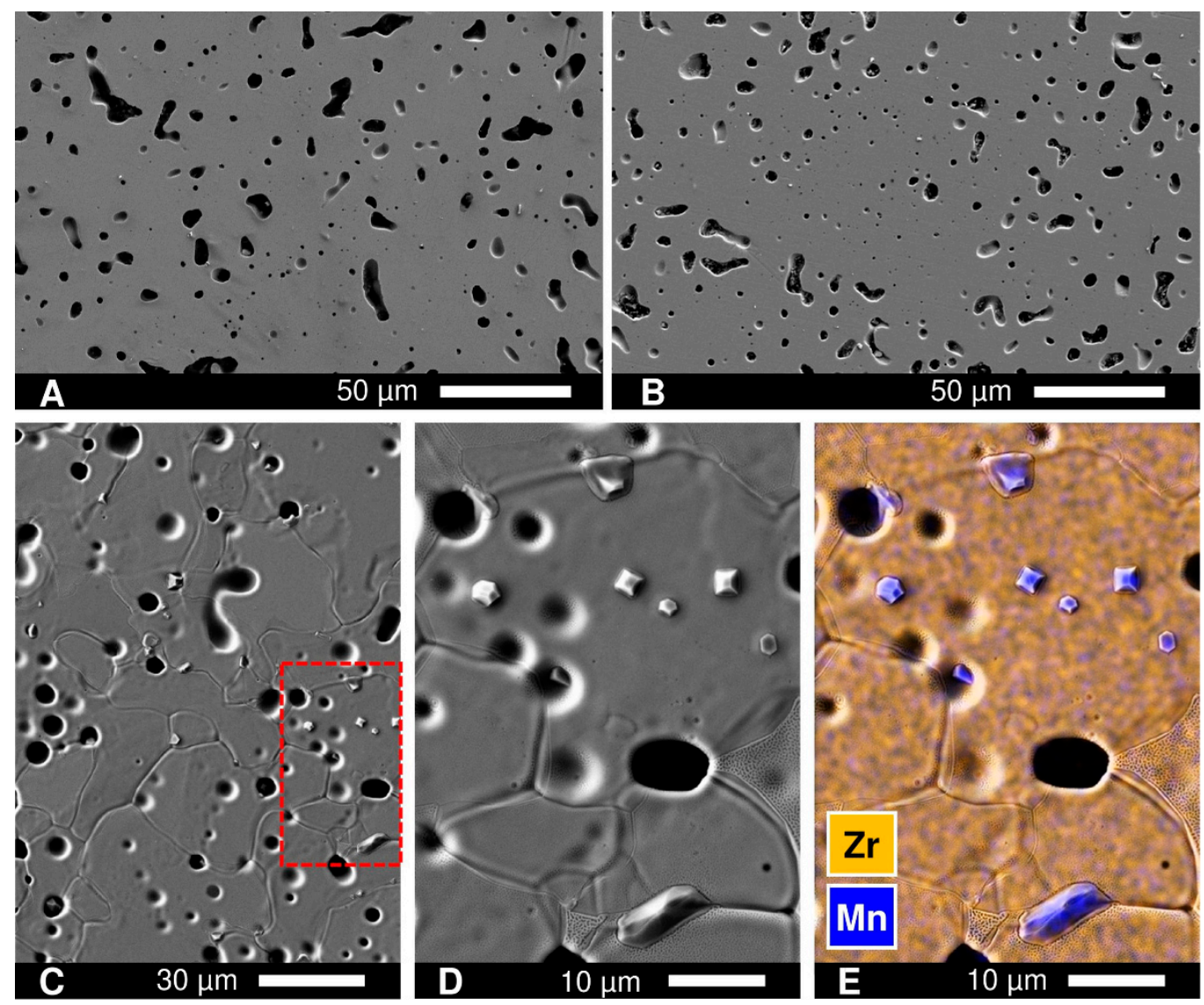

Figure 8. SEM images of the $x=0.15$ ceramics: (A) as-prepared polished; (B) polished and annealed in air at $900{ }^{\circ} \mathrm{C}$ for $360 \mathrm{~h}$; (C) polished and heated in air to $1400{ }^{\circ} \mathrm{C}$ with immediate cooling (heating/cooling at $5{ }^{\circ} \mathrm{C} / \mathrm{min}$ ); (D) magnified image of selected area in (C); and (E) magnified image with overlaid EDS elemental mapping.

Table 4. Observed $\mathrm{E}_{\mathrm{exp}} / \mathrm{E}_{\mathrm{th}}$ values and oxygen-ion transference numbers obtained by the modified electromotive force $(E M F)$ technique before and after relaxation $(>70 \mathrm{~h})$ at $900^{\circ} \mathrm{C}$ under air $/ \mathrm{O}_{2}$ gradient.

\begin{tabular}{cccccc}
\hline \multirow{2}{*}{$\boldsymbol{x}$} & \multicolumn{2}{c}{ Before Relaxation } & \multicolumn{2}{c}{ After Relaxation } & \multirow{2}{*}{$\mathbf{R}_{\text {after }} / \mathbf{R}_{\text {ini }}{ }^{\mathbf{1}}$} \\
\cline { 2 - 5 } & $\mathbf{E}_{\text {exp/ }} / \mathbf{E}_{\text {th }}$ & $\overline{\mathbf{t}_{\mathbf{O}}}$ & $\mathbf{E}_{\mathbf{e x p} / \mathbf{E}_{\text {th }}}$ & $\overline{\mathbf{t}_{\mathbf{O}}}$ & \\
\hline 0.05 & 0.984 & 0.990 & 0.957 & 0.968 & 1.83 \\
0.10 & 0.52 & 0.62 & 0.42 & 0.50 & 0.86 \\
0.15 & 0.47 & - & 0.13 & 0.14 & 0.59 \\
\hline
\end{tabular}

${ }^{1} R_{\text {after }}$ and $R_{\text {ini }}$ are the values of ohmic resistance of the sample after and before relaxation, respectively.

Figure 9A shows the temperature dependence of the average oxygen-ion transference numbers of Mn-substituted 5YSZ under air/oxygen gradient after equilibration at $900{ }^{\circ} \mathrm{C}$. All compositions demonstrated negligible dependence of $\overline{\mathrm{t}_{\mathrm{O}}}$ on temperature at $700-900{ }^{\circ} \mathrm{C}$. 
Substitution by manganese leads to a gradual transformation from a predominantly ionic conductor $(x=0.05)$ to a mixed conductor with similar contributions of ionic and electronic transport $(x=0.10)$, and then to a material with prevailing electronic conduction $(x=0.15)$ under oxidizing conditions close to air.
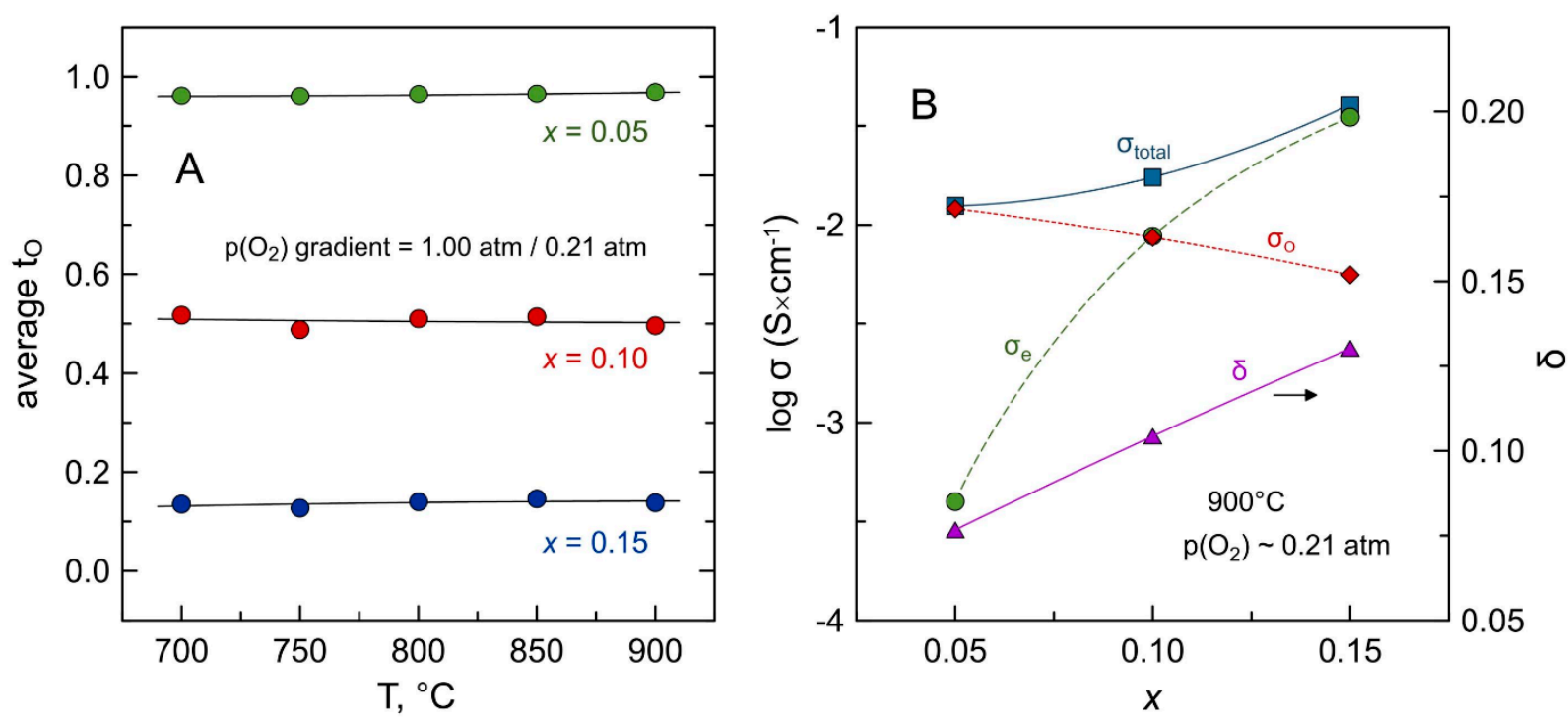

Figure 9. (A) Temperature dependence of average oxygen-ion transference numbers of Mn-substituted 5YSZ ceramics under air $/ \mathrm{O}_{2}$ gradient; and (B) total and partial ionic and electronic conductivities and oxygen deficiency (per $\mathrm{AO}_{2}$ formula unit) at $900{ }^{\circ} \mathrm{C}$ in air as function of $\mathrm{Mn}$ content. The values of $\sigma_{\mathrm{O}}$ and $\sigma_{\mathrm{e}}$ are estimated from the data on total conductivity in air and average $t_{\mathrm{O}}$ under air $/ \mathrm{O}_{2}$ gradient. All values were obtained after isothermal relaxation at $900{ }^{\circ} \mathrm{C}\left(\geq 70 \mathrm{~h}\right.$ for $\mathrm{t}_{\mathrm{O}}$; $\geq 25 \mathrm{~h}$ for $\sigma ; \geq 10 \mathrm{~h}$ for $\delta$ ).

Calculations of partial contributions to total conductivity demonstrated that increasing Mn concentration in the fluorite lattice results in the gradual enhancement of electronic transport but simultaneously suppresses ionic conduction (Figure 9B). Yttria-doped zirconia is known to exhibit very low $p$-type electronic conductivity under oxidizing conditions. For instance, the electronic conductivity of $8 \mathrm{YSZ}$ in air at $900{ }^{\circ} \mathrm{C}$ was reported to be as low as $\sim 10^{-5} \mathrm{~S} \times \mathrm{cm}^{-1}$ [57]. Additions of manganese lead to an increase in electronic conductivity by orders of magnitude (Figure 9B). Similar observations were previously reported for Mn-doped 3YSZ [22] and 8YSZ [19,21-24] within the manganese solubility ranges.

Oxygen-ionic conductivity of Mn-substituted 5 YSZ at $900{ }^{\circ} \mathrm{C}$ decreases twice with increasing Mn content (from $1.2 \mathrm{mS} \times \mathrm{cm}^{-1}$ for $x=0.05$ to $0.56 \mathrm{mS} \times \mathrm{cm}^{-1}$ for $x=0.15$ ), despite an increase in the concentration of oxygen vacancies (Figure 9B), and is lower compared to $8 \mathrm{YSZ}\left(\delta=0.074, \sigma_{\mathrm{O}}=10 \mathrm{mS} \times \mathrm{cm}^{-1}\right.$ at $900{ }^{\circ} \mathrm{C}$ [58]). It is known that zirconia-based solid electrolytes exhibit the highest oxygen-ionic conductivity when the concentration of acceptor-type dopant (alkaline-earth or rare-earth cation) is close to the minimum required for the stabilization of cubic fluorite structure $[59,60]$. For the $\left(\mathrm{ZrO}_{2}\right)_{1-x}\left(\mathrm{Y}_{2} \mathrm{O}_{3}\right)_{x}$ system, this corresponds to $x=0.08-0.10[60,61]$. Further substitution results in a decline in the ionic conductivity, mainly due to defect association that causes a decrease in the mobility of ionic charge carriers. As for other zirconia-based systems, a decrease in $\sigma_{O}$ with manganese content in the studied range of solid solution can be assigned, most likely, to coulombic interaction between the point defects, manganese cations $\mathrm{Mn}_{\mathrm{Zr}}^{\prime \prime}$ and $\mathrm{Mn}_{\mathrm{Zr}}^{\prime}$ and oxygen vacancies $\mathrm{V}_{\mathrm{O}}^{\bullet \bullet}$, and formation of complex defect associates. Previously, Appel et al. [54,62] suggested the association of manganese ions and oxygen vacancies and the formation of ordered microdomains in Mn-doped 7.5YSZ (5-10 mol.\% of $\mathrm{MnO}_{y}$ ), based on EELS and electron diffraction studies. Kawada et al. [19] found that the ionic conductivity in Mn-substituted 8YSZ in air increases with manganese substitution of up to 4 mol.\% of $\mathrm{MnO}_{\mathrm{y}}$, and declines on further substitution; they also attributed it to the defect association 
at high Mn substitution levels. An additional factor possibly contributing to the decrease in ionic transport with Mn substitution is the strain caused by lattice shrinkage, which may result in an increase in the migration barrier for oxygen ion diffusion [24].

The behavior of total electrical conductivity vs oxygen partial pressure under oxidizing conditions, in the $\mathrm{p}\left(\mathrm{O}_{2}\right)$ range between $10^{-5}$ and $1.0 \mathrm{~atm}$ (Figure 10), is an interplay between ionic and electronic contributions to electrical transport, and is defined by dominating charge carriers. For all compositions, the defect equilibrium is governed by

$$
\mathrm{Mn}_{\mathrm{Zr}}^{\prime \prime}+\frac{1}{2} \mathrm{~V}_{\mathrm{O}}^{\bullet \bullet}+\frac{1}{4} \mathrm{O}_{2} \underset{\mathrm{pO}_{2} \downarrow}{\stackrel{\mathrm{pO}_{2} \uparrow}{\rightleftarrows}} \mathrm{Mn}_{\mathrm{Zr}}^{\prime}+\frac{1}{2} \mathrm{O}_{\mathrm{O}^{\prime}}^{\times}
$$

or

$$
\mathrm{V}_{\mathrm{O}}^{\bullet \bullet}+\frac{1}{2} \mathrm{O}_{2} \underset{\mathrm{pO}_{2} \downarrow}{\stackrel{\mathrm{pO}_{2} \uparrow}{\rightleftarrows}} \mathrm{O}_{\mathrm{O}}^{\times}+2 \mathrm{~h}^{\bullet},
$$

where $\mathrm{h}^{\bullet}$ is the electron-hole, in combination with the electroneutrality condition given by Equation (3). The contribution of electronic transport to the total conductivity in the $x=0.05$ ceramics is only a few percent in air. As a result, the total conductivity of this material shows a moderate increase with reducing $\mathrm{p}\left(\mathrm{O}_{2}\right)$ due to an increase in the oxygen vacancy concentration, and therefore, ionic conductivity. Similar behavior was reported for 3YSZ with 3.0-7.6 mol.\% $\mathrm{MnO}_{y}$ under oxidizing conditions at $1000-1100{ }^{\circ} \mathrm{C}$ [29]. On the contrary, electronic conductivity prevails in the $x=0.15$ sample in air, when electron holes should become the dominant charge carriers. Note that the contribution of polarons by transfer between $\mathrm{Mn}^{3+}$ and $\mathrm{Mn}^{2+}$ is less likely, due to the diluted state of manganese cations in the fluorite lattice. Reducing $\mathrm{p}\left(\mathrm{O}_{2}\right)$ is accompanied by a decrease in $\left[\mathrm{h}^{\bullet}\right], p$-type electronic transport and the total conductivity. This coincides with the dependencies observed for $8 Y S Z$ doped by $6-10 \mathrm{~mol} . \% \mathrm{MnO}_{\mathrm{y}}$ under oxidizing conditions $[20,24]$. The $x=0.10$ solid solution with the electronic transference number close to 0.5 in air exhibits smother variations of $\sigma_{\text {total }}$ with oxygen partial pressure compared to the $x=0.15$ ceramics. For all compositions, the dependencies of defect concentration and electrical conductivity become weaker at lower temperatures.

Note also that the obtained $\sigma-\mathrm{p}\left(\mathrm{O}_{2}\right)$ dependencies under oxidizing conditions agree well with the trends in variation of conductivity and transference numbers during the initial relaxation of as-prepared samples at $900{ }^{\circ} \mathrm{C}$ (Figure 7). Slow oxygen uptake with time is associated with the oxidation of manganese cations, generation of electron-holes and elimination of oxygen vacancies, leading to a decrease in ionic conductivity and an increase in hole transport. Considering the non-negligible and nearly reversible changes of the oxygen content on temperature cycling (Figure 5), a slow oxygen exchange with the gas phase cannot be a reason for a prolonged equilibration of the samples at $900{ }^{\circ} \mathrm{C}$. The slow processes of defect association and clustering seem to be a more likely explanation, although more detailed studies are required to find the exact reasons. 

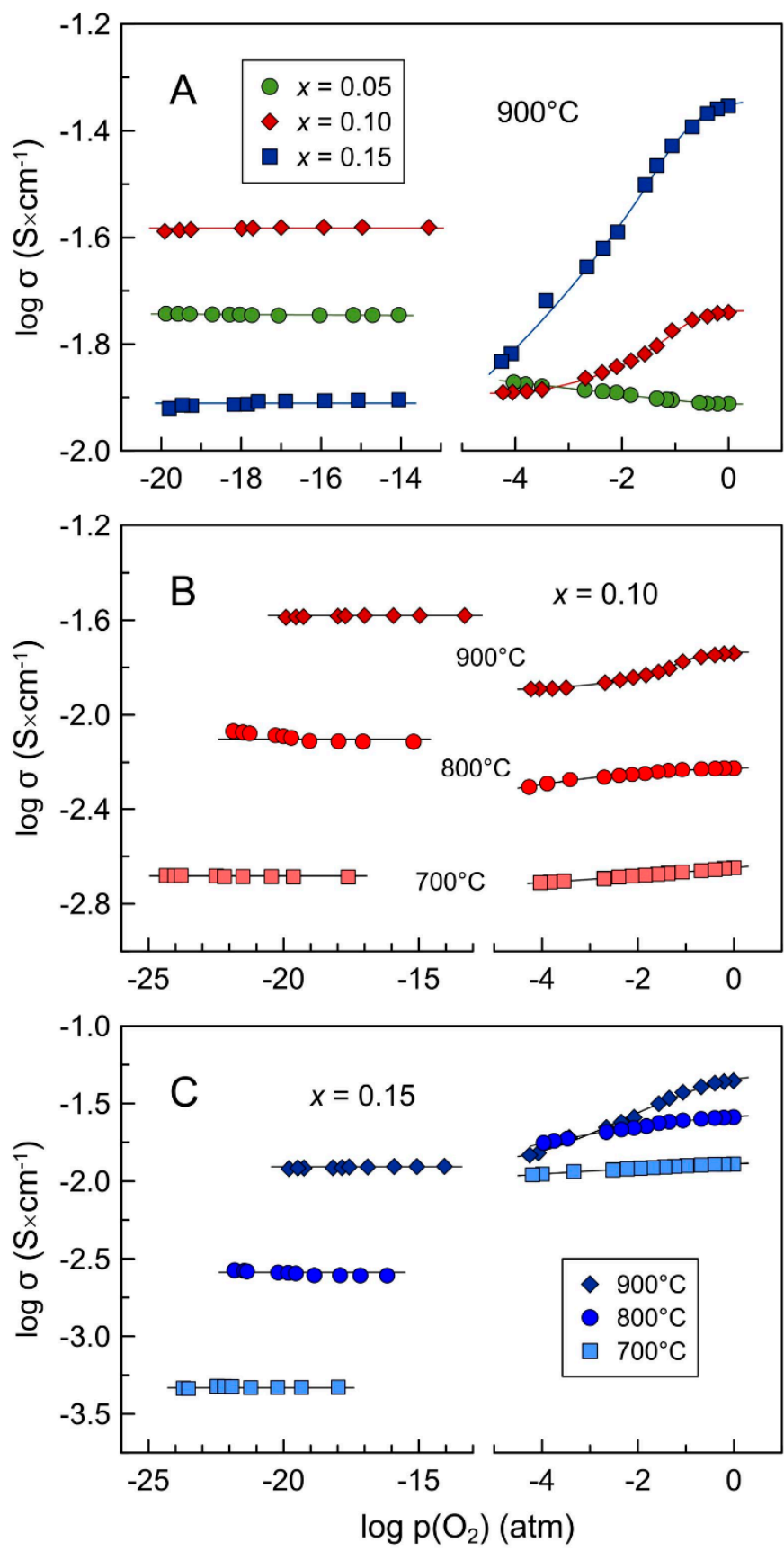

Figure 10. Oxygen partial pressure dependence of electrical conductivity of (A) Mn-substituted 5YSZ ceramics at $900{ }^{\circ} \mathrm{C}$; (B) $x=0.10$ ceramics at $700-900{ }^{\circ} \mathrm{C}$; and (C) $x=0.15$ ceramics at $700-900{ }^{\circ} \mathrm{C}$.

\subsection{Cycling between Oxidizing and Reducing Conditions}

Thermogravimetric studies showed that all Mn-substituted 5YSZ powdered samples demonstrate an apparently reversible behavior on cycling between air and $10 \% \mathrm{H}_{2}-\mathrm{N}_{2}$ atmospheres at $900{ }^{\circ} \mathrm{C}$ (Figure 11A). The samples show a slow oxygen uptake with time in air, but nearly instantly lose oxygen upon switching to a reducing atmosphere, and then exhibit a constant weight suggesting a full reduction of manganese cations to a $2+$ oxidation state. Switching back to oxidizing atmosphere results in a rapid oxidation to a state corresponding to the mean manganese valence of 2.55-2.60. This is followed, again, by a slow further oxidation. 

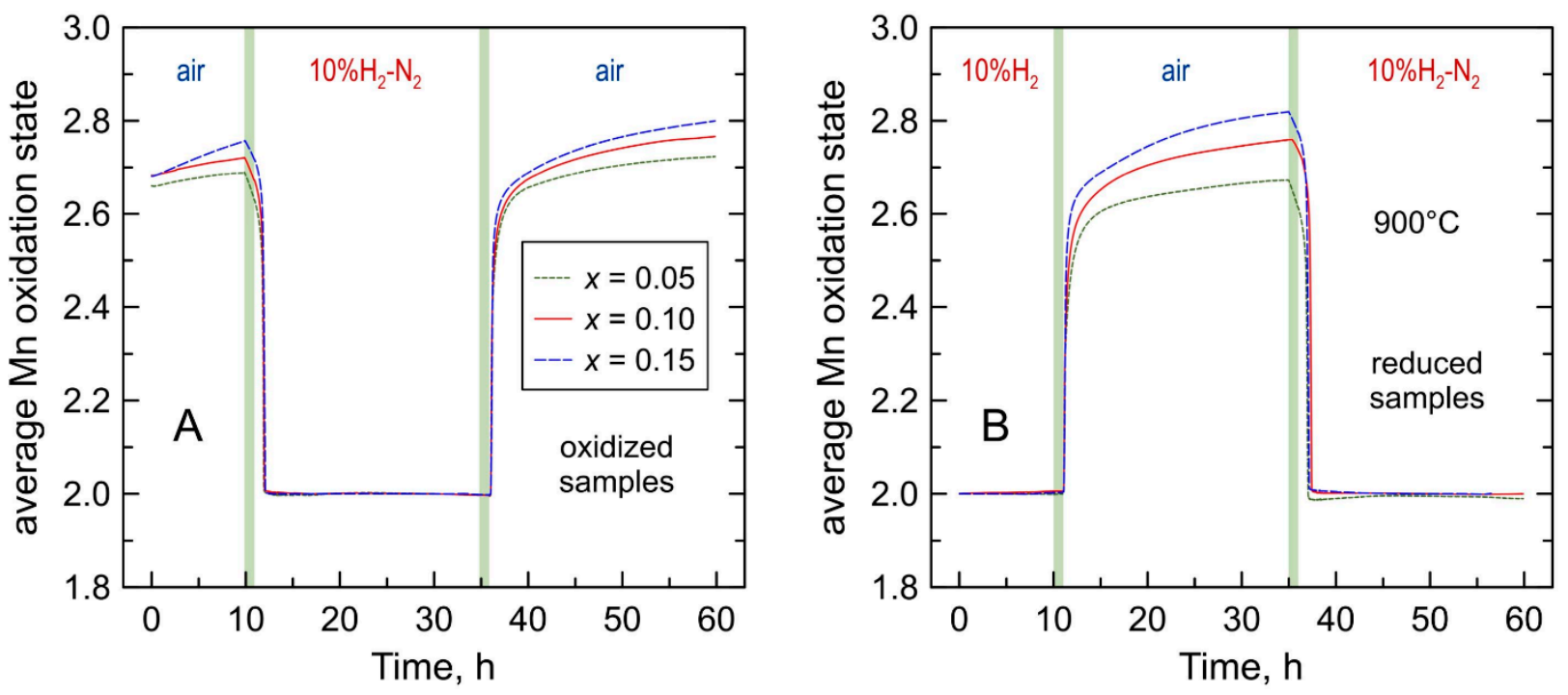

Figure 11. Variations of average manganese oxidation state in Mn-substituted 5YSZ on redox cycling at $900{ }^{\circ} \mathrm{C}:(\mathrm{A})$ oxidized samples in ox $\rightarrow$ red $\rightarrow$ ox cycles; and (B) reduced samples $\left(24 \mathrm{~h}\right.$ in $10 \% \mathrm{H}_{2}-\mathrm{N}_{2}$ flow at $900{ }^{\circ} \mathrm{C}$ ) in red $\rightarrow$ ox $\rightarrow$ red cycle.

XRD analysis confirmed that all samples remain single-phase solid solutions with cubic fluorite structure after annealing in $10 \% \mathrm{H}_{2}-\mathrm{N}_{2}$ flow for $24 \mathrm{~h}$ at $900{ }^{\circ} \mathrm{C}$ (Figure 1C). The reduction leads to an expansion of the fluorite lattice (Figure 3) caused by an increase in the average ionic radius of manganese cation on $\mathrm{Mn}^{3+/ 2+} \rightarrow \mathrm{Mn}^{2+}$ transformation. Thermogravimetric studies also confirmed that manganese oxidation state, and therefore the oxygen nonstoichiometry remains constant on thermal cycling in $10 \% \mathrm{H}_{2}-\mathrm{N}_{2}$ atmosphere (Figure 12A), and that the reduced samples exhibit a reversible behavior on isothermal cycling between reducing and oxidizing atmospheres (Figure 11B).
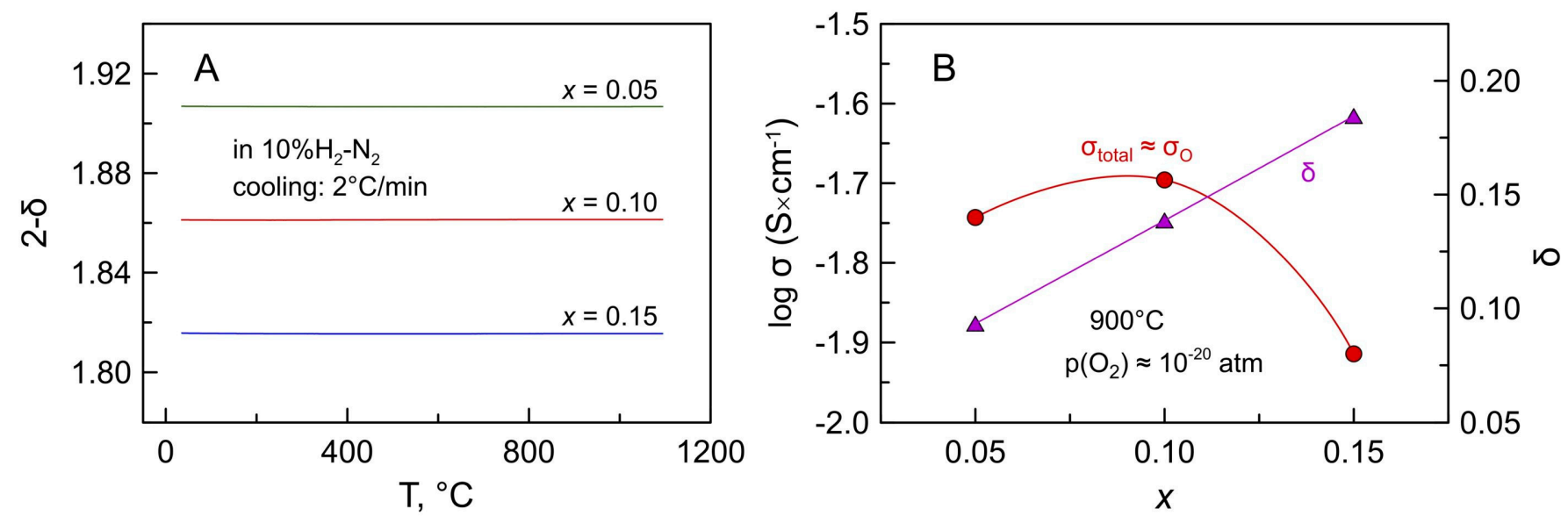

Figure 12. (A) Oxygen nonstoichiometry (per $\mathrm{AO}_{2}$ formula unit) of reduced Mn-substituted 5YSZ on cooling in reducing atmosphere; and (B) Total/ionic conductivity and oxygen deficiency of reduced Mn-substituted 5YSZ at $900{ }^{\circ} \mathrm{C}$ as a function of Mn content.

Electrical studies demonstrated that reduced Mn-substituted 5YSZ ceramics exhibit essentially $\mathrm{p}\left(\mathrm{O}_{2}\right)$-independent electrical conductivity under reducing conditions (Figure 10). Reduction at $900{ }^{\circ} \mathrm{C}$ resulted in an enhancement of total conductivity of $x=0.05-0.10$ ceramics compared to oxidizing conditions; the degree of this enhancement diminishes with decreasing temperature. On the contrary, the $x=0.15$ samples showed a drop in electrical conductivity after reduction at $900{ }^{\circ} \mathrm{C}$, and the extent of this drop became larger with decreasing temperature. Table 5 summarizes the results of measurements of average 
oxygen-ion transference numbers using air $/\left(10 \% \mathrm{H}_{2}-\mathrm{N}_{2}\right)$ concentration cells. The results suggest that all Mn-substituted 5YSZ ceramics are ionic conductors under reducing conditions with negligible contribution of electronic transport. Thus, the reduction-induced changes in conductivity are in agreement with the expected changes in the concentration of defects as described by Equations (4) and (5): a decrease in electron-hole concentration and $p$-type electronic transport and an increase in oxygen-vacancy concentration and ionic conductivity. Apparently, manganese cations remain in a 2+ oxidation state in the studied $\mathrm{p}\left(\mathrm{O}_{2}\right)$ range under reducing conditions resulting in $\mathrm{p}\left(\mathrm{O}_{2}\right)$-independent total (ionic) conductivity. This is in agreement with the data on manganese oxidation state in doped 9.5YSZ single crystals (Mn content $\leq 0.1 \mathrm{wt} . \%$ ) determined by combined EPR and optical absorption measurements $[49,50,52,53]$, and also with the results of thermodynamic modeling of the Zr-Y-Mn-O system [51].

Table 5. Oxygen-ion transference number obtained by the modified EMF technique using air/(10\% $\mathrm{H}_{2}-\mathrm{N}_{2}$ ) concentration cells.

\begin{tabular}{|c|c|c|c|c|c|c|}
\hline \multirow{2}{*}{$\mathrm{T},{ }^{\circ} \mathrm{C}$} & \multicolumn{2}{|c|}{$x=0.05$} & \multicolumn{2}{|c|}{$x=0.10$} & \multicolumn{2}{|c|}{$x=0.15$} \\
\hline & $\log p_{1}(\text { atm })^{1}$ & $\overline{\mathbf{t}_{\mathrm{O}}}$ & $\log p_{1}(\mathrm{~atm})$ & $\overline{\mathbf{t}_{\mathrm{O}}}$ & $\log p_{1}(\mathrm{~atm})$ & $\overline{t_{O}}$ \\
\hline 900 & -19.4 & 0.9991 & -18.2 & 0.983 & -17.4 & 0.997 \\
\hline 850 & -20.4 & 0.9995 & -19.3 & 0.991 & -18.4 & 0.997 \\
\hline 800 & -21.2 & 0.9996 & -20.5 & 0.992 & -19.3 & 0.997 \\
\hline 750 & -21.4 & 0.9997 & -21.6 & 0.990 & -20.2 & 0.996 \\
\hline 700 & -21.5 & 0.9996 & -23.0 & 0.986 & -20.9 & 0.995 \\
\hline
\end{tabular}

${ }^{1} p_{1}$ is the oxygen partial pressure in $10 \% \mathrm{H}_{2}-\mathrm{N}_{2}$ flow measured by oxygen sensor.

Figure 12B shows the composition dependence of ionic conductivity in Mn-substituted $5 \mathrm{YSZ}$ at $900{ }^{\circ} \mathrm{C}$ under reducing conditions. While oxygen vacancy concentration increases linearly with Mn content, $\sigma_{\mathrm{O}}$ goes through a maximum $\left(2 \mathrm{mS} \times \mathrm{cm}^{-1}\right)$ at $x \sim 0.10$, although still being lower compared to $8 \mathrm{YSZ}\left(10 \mathrm{mS} \times \mathrm{cm}^{-1}\right.$ [58]). This differs from the results obtained under oxidizing conditions where ionic conductivity decreases with increasing $\mathrm{Mn}$ content, presumably due to the increasing impact of the defect association. All manganese is in a 2+ oxidation state under reducing conditions, and $\mathrm{Mn}^{2+}$ cations have a stronger tendency to form dopant-vacancy pair clusters (a lower dopant-vacancy binding energy) compared to $\mathrm{Mn}^{3+}$ [63]. The observed maximum of ionic conductivity for $x=0.10$ under reducing conditions may imply the relevance of steric effects, namely lattice expansion on reduction with an impact on the oxygen-ion mobility.

The electrical studies also showed that the reducibility or reduction kinetics of at least bulk samples decreases with reducing temperature down to $700-800{ }^{\circ} \mathrm{C}$. As an example, Figure 13A compares the $\sigma-\mathrm{p}\left(\mathrm{O}_{2}\right)$ data at $700-800{ }^{\circ} \mathrm{C}$ for the $x=0.10$ samples reduced under different conditions. The sample preliminary reduced at $900{ }^{\circ} \mathrm{C}$ was found to exhibit higher conductivity than the sample reduced at 700 or $800{ }^{\circ} \mathrm{C}$.

Another observation is that treatments under reducing conditions promote certain microstructural changes of the ceramics surface. SEM/EDS inspection of polished $x=0.10$ and $x=0.15$ samples after annealing in $10 \% \mathrm{H}_{2}-\mathrm{N}_{2}$ flow at $900{ }^{\circ} \mathrm{C}$ for $240 \mathrm{~h}$ revealed the irregular accumulation of $\mathrm{MnO}_{y}$ both at the grain boundaries and at the surface of grains, particularly around and inside the pores (Figure 14). Segregation of $\mathrm{MnO}_{y}$ was also detected on the surface of ceramics samples after prolonged electrical measurements under reducing conditions at $700-900{ }^{\circ} \mathrm{C}$. It should be noted that the manganese oxide exsolution under reducing conditions was rather surprising given that it was not observed under oxidizing conditions even after longer annealing (Figure 8B) and that the thermodynamic calculations predict an increase in Mn solubility on reduction [51]. Nonetheless, the experimental results imply that reducing conditions promote the exsolution of excess manganese from the fluorite lattice, even though the process is sluggish and is likely to be limited to the exposed grain boundaries and surface. 

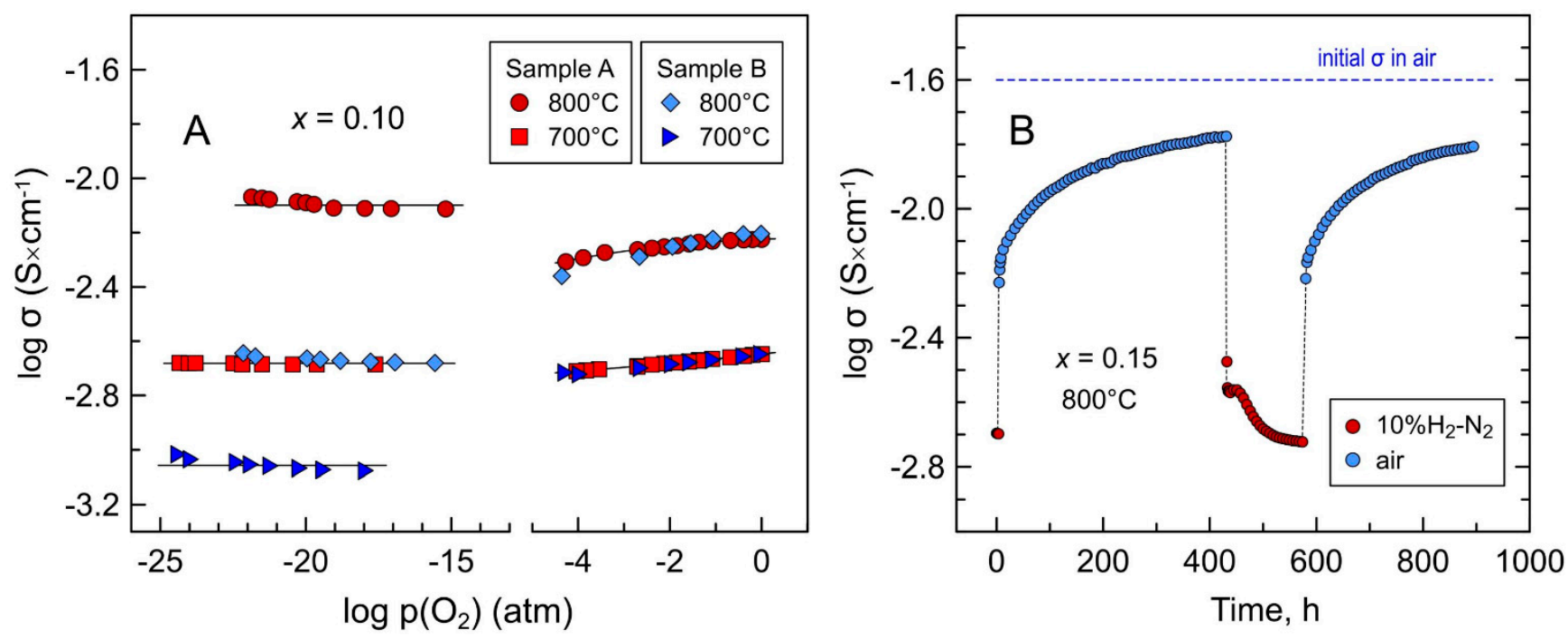

Figure 13. (A) Oxygen partial pressure dependence of electrical conductivity of $x=0.10$ samples measured in different regimes. Sample A: measurements were done first in oxidizing and then in reducing atmospheres with reduction at $900{ }^{\circ} \mathrm{C}$. Sample B: measurements were done first at $800{ }^{\circ} \mathrm{C}$ and then at $700{ }^{\circ} \mathrm{C}$ with reduction at given T. (B) Variations of electrical conductivity of the $x=0.15$ ceramics on cycling between reducing and oxidizing atmospheres at $800{ }^{\circ} \mathrm{C}$. The experiment was conducted after $\sigma-\mathrm{p}\left(\mathrm{O}_{2}\right)$ measurements under oxidizing and then under reducing conditions at $700-900{ }^{\circ} \mathrm{C}$.
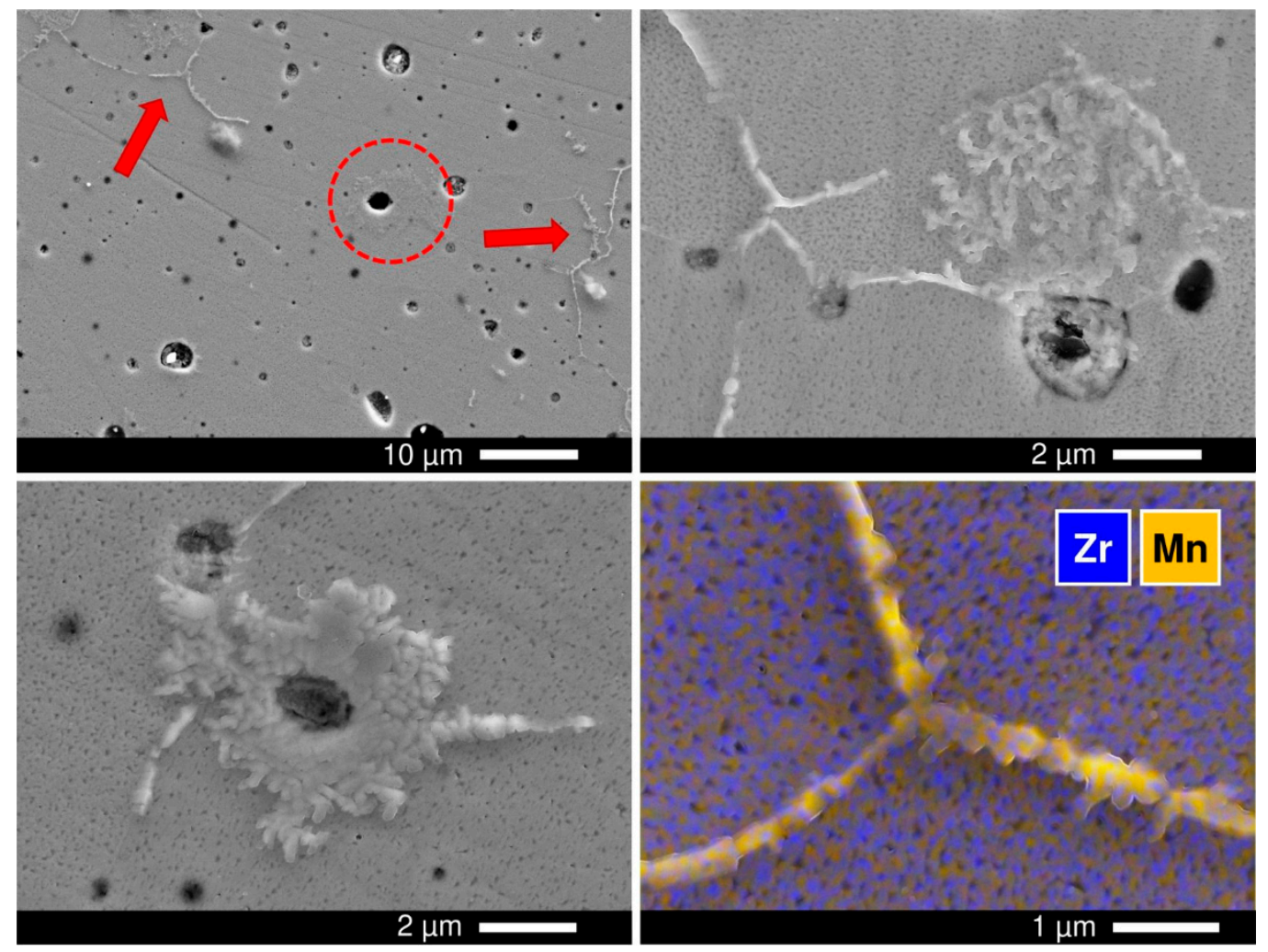

Figure 14. SEM images of polished $x=0.10$ sample annealed in $10 \% \mathrm{H}_{2}-\mathrm{N}_{2}$ flow at $900{ }^{\circ} \mathrm{C}$ for $240 \mathrm{~h}$. The image in the right bottom corner is an SEM micrograph with overlaid EDS elemental mapping.

Reduction-induced microstructural changes at the surface seem to be responsible for not entirely reversible changes in electrical conductivity on cycling between oxidizing and reducing conditions. An example is shown in Figure 13B for the $x=0.15$ ceramics at 
$800^{\circ} \mathrm{C}$. The sample showed an apparently reproducible variation of conductivity, with a faster decrease on reduction and slower recovery during oxidation. However, the level of conductivity dropped compared to the initial value obtained during initial measurements under oxidizing conditions. Post-mortem XRD analysis of that sample (crushed into powder) still showed the cubic fluorite structure with no evidence of phase impurities.

\subsection{Thermochemical Expansion}

The dilatometric curves of Mn-substituted 5YSZ ceramics in air exhibit a non-linear behavior, and can be approximated by three segments in the studied temperature range (Figure 15A). In the low-temperature range below $\sim 400{ }^{\circ} \mathrm{C}$, when the oxygen exchange with the gas phase is frozen, the observed expansion of oxide materials corresponds to the "true" thermal expansion of the lattice originating from the anharmonicity of atomic vibrations. Increasing temperature gives rise to a "chemical" contribution to the thermochemical expansion $[64,65]$ associated with the increase in $\left[\mathrm{Mn}^{2+}\right] /\left[\mathrm{Mn}^{3+}\right]$ ratio on heating due to oxygen losses from the lattice and the reduction of Mn cations, and consequently an increase in their average ionic radius. The changes in the slope of dilatometric curves reflect the corresponding inflections in temperature dependencies of the oxygen nonstoichiometry and the mean manganese valence (Figure 15A).
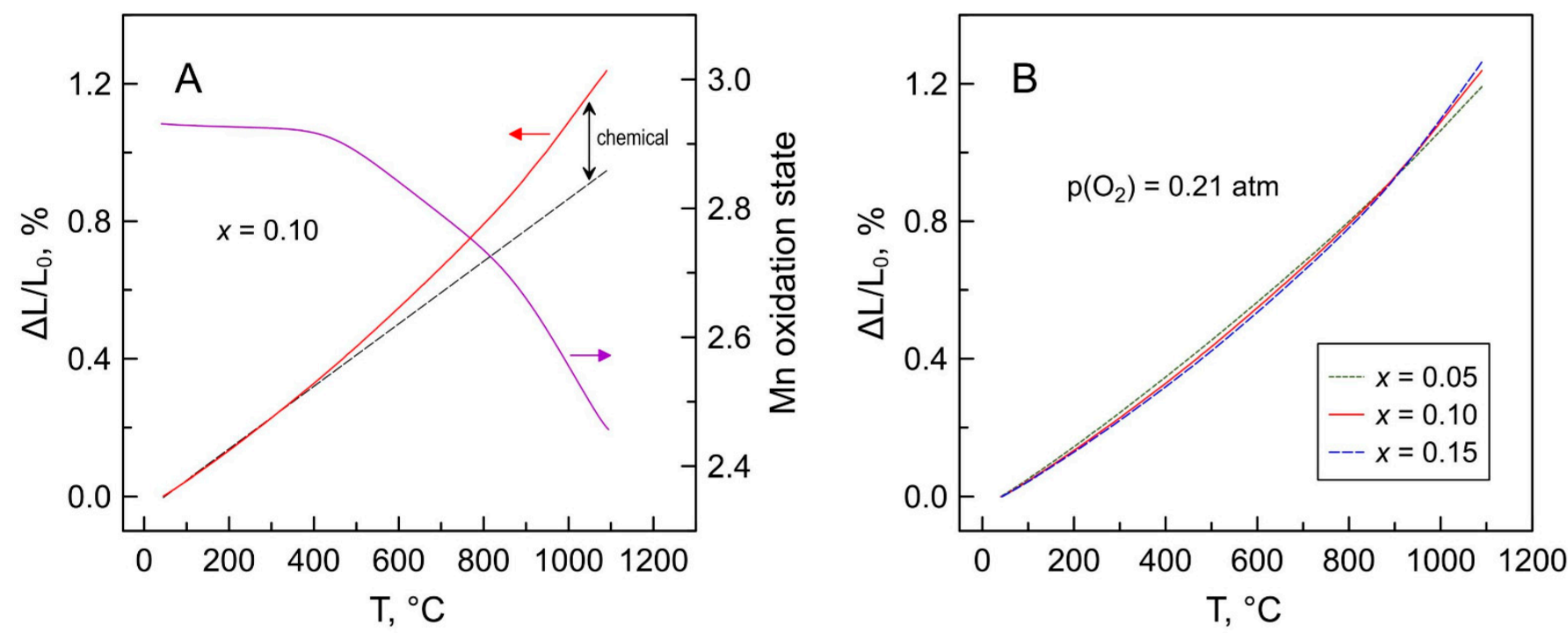

Figure 15. (A) Relative elongation of the $x=0.10$ ceramics in air and corresponding changes in average Mn oxidation state; and (B) dilatometric curves of Mn-substituted 5YSZ ceramics in air.

In the low-temperature range, the average linear thermal expansion coefficients (TECs) of the Mn-substituted 5YSZ ceramics decrease slightly with increasing manganese content (Figure 15B and Table 6), in correlation with changes in the lattice parameter (Figure 3). On the contrary, average TEC values increase with Mn content in the high-temperature range, particularly above $\sim 850^{\circ} \mathrm{C}$, due to the increasing contribution of the chemical expansion. Still, the average thermal expansion coefficients of prepared Mn-substituted 5YSZ ceramics at $25-1100{ }^{\circ} \mathrm{C}$ (Table 6) is comparable to that of the 8YSZ solid electrolyte $(10.7-10.9 \mathrm{ppm} / \mathrm{K}[66,67])$, while somewhat excessive expansion at higher temperatures may be useful for buffer interlayers to bridge the gap between TECs of zirconiabased solid electrolyte and oxygen electrode materials including classical ( $\mathrm{Ln}, \mathrm{A}) \mathrm{MnO}_{3+\delta}$ (10-13 ppm/K [67-69]), state-of-the-art $\quad(\mathrm{La}, \mathrm{Sr}) \mathrm{Co}_{0.2} \mathrm{Fe}_{0.8} \mathrm{O}_{3-\delta} \quad$ (LSCF) (average 14.8-15.4 ppm/K [69] but up to $22.0-24.5 \mathrm{ppm} / \mathrm{K}$ at $700-1100{ }^{\circ} \mathrm{C}$ [70]) or layered Ruddlesden-Popper $\mathrm{Ln}_{2} \mathrm{NiO}_{4-\delta}$-based nickelates (12-15 ppm/K [71]). 
Table 6. Average thermal expansion coefficients ${ }^{1}$ of Mn-substituted 5YSZ ceramics under oxidizing and reducing atmospheres.

\begin{tabular}{|c|c|c|c|c|}
\hline \multirow[t]{2}{*}{ Atmosphere } & \multirow[t]{2}{*}{ T Range, ${ }^{\circ} \mathrm{C}$} & \multicolumn{3}{|c|}{$\begin{array}{l}\text { Average Linear Thermal Expansion Coefficient } \\
\qquad(\alpha \pm 0.1) \times 10^{6}, \mathrm{~K}^{-1}\end{array}$} \\
\hline & & $x=0.05$ & $x=0.10$ & $x=0.15$ \\
\hline \multirow{4}{*}{ air } & $40-1100$ & 10.9 & 11.1 & 11.2 \\
\hline & $40-400$ & 9.5 & 9.0 & 8.7 \\
\hline & $400-850$ & 11.4 & 11.7 & 11.8 \\
\hline & $850-1100$ & 13.8 & 16.1 & 17.4 \\
\hline $10 \% \mathrm{H}_{2}-\mathrm{N}_{2}$ & $40-1100$ & 10.7 & 10.5 & 10.6 \\
\hline
\end{tabular}

${ }^{1}$ TEC values are calculated from the dilatometric data obtained on cooling in the corresponding atmosphere.

Heating the Mn-substituted 5YSZ ceramics in a reducing atmosphere results in a noticeable expansion between 400 and $600{ }^{\circ} \mathrm{C}$ caused by $\mathrm{Mn}^{2+/ 3+} \rightarrow \mathrm{Mn}^{2+}$ reduction (Figure 16A). After reduction, the materials show moderate dimensional changes on thermal cycling in a $10 \% \mathrm{H}_{2}-\mathrm{N}_{2}$ atmosphere with average TECs at $25-1100{ }^{\circ} \mathrm{C}$ even somewhat lower compared to that in air (Table 6), due to the constant $2+$ oxidation state of manganese cations under reducing conditions. The dimensional changes were reversible or nearly reversible on re-oxidation. Interestingly, the contraction of the reduced ceramics on heating in air occurs in two steps, in correlation with the oxygen nonstoichiometry variations in air (Figure 5), once again implying different oxygen exchange/diffusion kinetics and/or different defect structure in Mn-substituted zirconia at temperatures $\leq 800^{\circ} \mathrm{C}$ and $\geq 900^{\circ} \mathrm{C}$.
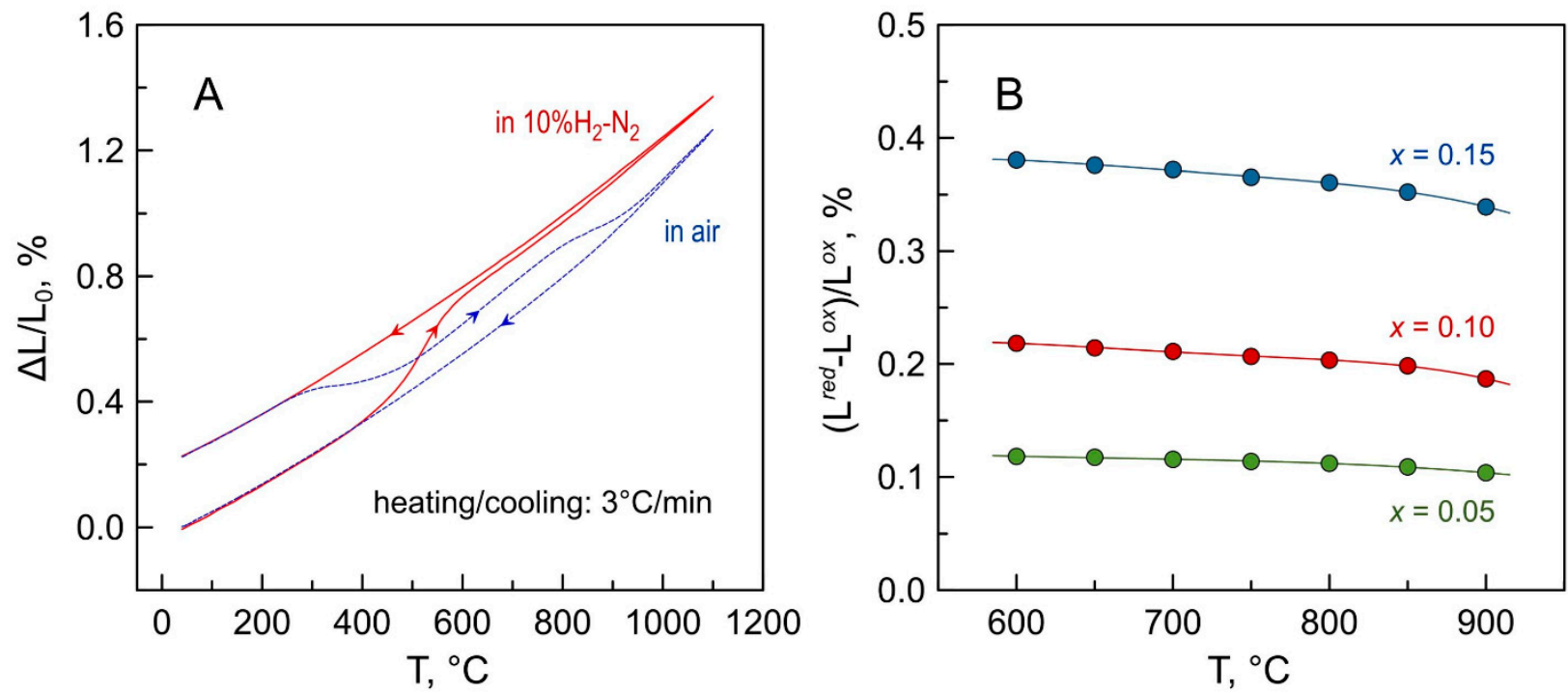

Figure 16. (A) Dimensional changes of oxidized $x=0.10$ ceramics in one heating/cooling cycle in $10 \% \mathrm{H}_{2}-\mathrm{N}_{2}$ atmosphere followed by a heating/cooling cycle in air; and (B) Temperature dependence of chemical expansion of oxidized Mnsubstituted 5 YSZ ceramics on reduction calculated from the dilatometric data on cooling in corresponding atmospheres.

Figure 16B shows the linear chemical expansion of Mn-substituted 5YSZ ceramics on reduction estimated from the dynamic dilatometric data on cooling in the corresponding atmospheres, and defined as $\left(\mathrm{L}^{r e d}-\mathrm{L}^{o x}\right) / \mathrm{L}^{o x}$ where $\mathrm{L}^{o x}$ and $\mathrm{L}^{\text {red }}$ are linear dimensions of the sample in oxidized and reduced states at a given temperature, respectively. Chemical expansion naturally increases with manganese additions, thus increasing the risk of stresses at the electrolyte/buffer layer interface in a hypothetical SOC configuration when Mnsubstituted 5YSZ is applied as an interlayer onto the 8YSZ electrolyte at the fuel side. At the same time, the dimensional changes on the reduction of $x=0.10$ ceramics are comparable to those of fuel electrode materials such as $\mathrm{La}(\mathrm{Sr}) \mathrm{Cr}(\mathrm{Mg}, \mathrm{Fe}) \mathrm{O}_{3-\delta}$ [72] or highly reduced 
$\mathrm{Sr}_{0.85} \mathrm{LnTiO}_{3-\delta}$ [73] under similar conditions. Furthermore, the chemical expansion of even $x=0.15$ ceramics is $\sim 3$ times lower compared to gadolinia-doped ceria $\mathrm{Ce}_{1-x} \mathrm{Gd}_{x} \mathrm{O}_{2-\delta}$ $(x=0.1-0.2)$, a conventional buffer layer material which exhibits a linear expansion of up to $\sim 1.2 \%$ on reducing $\mathrm{p}\left(\mathrm{O}_{2}\right)$ from atmospheric to $\sim 10^{-20}$ atm at $900{ }^{\circ} \mathrm{C}[74,75]$.

\section{Conclusions}

$\left.\left(\mathrm{ZrO}_{2}\right)_{0.95}\left(\mathrm{Y}_{2} \mathrm{O}_{3}\right)_{0.05}\right]_{1-x}\left[\mathrm{MnO}_{y}\right]_{x}(x=0.05,0.10$ and 0.15$)$ ceramics with cubic fluorite structure were prepared by solid-state synthesis and sintered in air at $1600{ }^{\circ} \mathrm{C}$. TGA complemented by XPS studies showed that Mn cations are in a mixed $2+/ 3+$ oxidation state under oxidizing conditions. The prepared materials exhibit variable oxygen nonstoichiometry on thermal cycling in air and on isothermal redox cycling between oxidizing and reducing atmospheres, and the extent of oxygen content variations increases with the Mn concentration. As-prepared Mn-substituted 5YSZ ceramics were found to undergo a slow oxidation under oxidizing conditions at $900{ }^{\circ} \mathrm{C}$, reflected by oxygen uptake, lattice shrinkage and changes in electrical properties. All the prepared materials show a lower total electrical conductivity compared to conventional 8YSZ solid electrolyte. Substitution by Mn gradually suppresses ionic conductivity, presumably due to defect association in the lattice, but increases $p$-type electronic conductivity under oxidizing conditions. This leads to a gradual transformation from a predominantly ionic conductor for $x=0.05$ to a mixed conductor with equal contributions of ionic and electronic transport for $x=0.10$ to material with prevailing electronic conduction for $x=0.15$. The reduction in $10 \% \mathrm{H}_{2}-\mathrm{N}_{2}$ atmosphere at $900{ }^{\circ} \mathrm{C}$ results in $\mathrm{Mn}^{2+/ 3+} \rightarrow \mathrm{Mn}^{2+}$ transformation accompanied by the lattice expansion, an increase in ionic conductivity and suppression of electronic transport. All studied Mn-substituted 5YSZ ceramics are ionic conductors under reducing conditions. Thermogravimetric and dilatometric studies demonstrated a reversible behavior in relatively short cycles between reducing and oxidizing atmospheres. Longer treatments under reducing conditions cause microstructural alterations at the surface of the bulk samples, with evidence of $\mathrm{MnO}$ exsolution, resulting in a not entirely reversible variation of the electrical conductivity on redox cycling. The Mn-substituted 5YSZ ceramics demonstrate an average thermal expansion coefficient similar to that of 8YSZ, although Mn additions gradually increase unfavorable chemical contribution to thermochemical expansion in air and dimensional changes on reduction.

Considering different factors such as the extent of oxygen nonstoichiometry variations (oxygen storage capacity), levels of ionic and electronic conductivity and thermochemical expansion, Mn-substituted 5YSZ with $0.05 \leq x<0.10$ seems to be the most suited for the application as a thin interlayer between electrolyte and oxygen electrode of reversible SOCs.

Author Contributions: Conceptualization and methodology, A.A.Y. and J.R.F.; investigation, A.N., A.A.Y. and A.Ż.; data analysis, A.N., A.A.Y., B.I.A.-S., E.R.-C. and J.R.F.; writing-original draft preparation, A.A.Y., A.N. and B.I.A.-S.; writing-review and editing, A.N., B.I.A.-S., E.R.-C., A.Ż., J.R.F. and A.A.Y.; supervision, project administration and funding acquisition, J.R.F. and A.A.Y. All authors have read and agreed to the published version of the manuscript.

Funding: PhD scholarship of A.N. is funded by the FCT (grant SFRH/BD/116853/2016). This work was supported by the projects HEALING (POCI-01-0145-FEDER-032036) and CARBOSTEAM (POCI-01-0145-FEDER-032295) funded by FEDER through COMPETE2020-Programa Operacional Competitividade e Internacionalização (POCI) and by national funds through FCT/MCTES, and by the project CICECO-Aveiro Institute of Materials (UIDB/50011/2020 \& UIDP/50011/2020) financed by national funds through the FCT/MCTES and when appropriate co-financed by FEDER under the PT2020 Partnership Agreement. E.R.-C. thanks to project RTI2018-099668-BC22 of Ministerio de Ciencia, Innovación y Universidades and FEDER funds. A.Ż. gratefully acknowledges financial support from the Ministry of Science and Higher Education of the Republic of Poland for Statutory Grant CPE/098/STAT-MN-AZ/20 in the Institute of Power Engineering.

Data Availability Statement: Data is contained within the article and/or available from the corresponding author upon reasonable request. 
Conflicts of Interest: The authors declare no conflict of interest.

\section{References}

1. Mogensen, M.B.; Chen, M.; Frandsen, H.L.; Graves, C.; Hansen, J.B.; Hansen, K.V.; Hauch, A.; Jacobsen, T.; Jensen, S.H.; Skafte, T.L.; et al. Reversible solid-oxide cells for clean and sustainable energy. Clean Energy 2019, 3, 175-201. [CrossRef]

2. Hauch, A.; Küngas, R.; Blennow, P.; Hansen, A.B.; Hansen, J.B.; Mathiesen, B.V.; Mogensen, M.B. Recent advances in solid oxide cell technology for electrolysis. Science 2020, 370, eaba6118. [CrossRef] [PubMed]

3. Hughes, G.A.; Yakal-Kremski, K.; Barnett, S.A. Life testing of LSM-YSZ composite electrodes under reversing-current operation. Phys. Chem. Chem. Phys. 2013, 15, 17257-17262. [CrossRef]

4. Moçoteguy, P.; Brisse, A. A review and comprehensive analysis of degradation mechanisms of solid oxide electrolysis cells. Int. J. Hydrogen Energy 2013, 38, 15887-15902. [CrossRef]

5. Wang, Y.; Li, W.; Ma, L.; Li, W.; Liu, X. Degradation of solid oxide electrolysis cells: Phenomena, mechanisms, and emerging mitigation strategies-A review. J. Mater. Sci. Technol. 2020, 55, 35-55. [CrossRef]

6. Chen, K.; Jiang, S.P. Review-Materials degradation of solid oxide electrolysis cells. J. Electrochem. Soc. 2016, 163, F3070-F3083. [CrossRef]

7. Zheng, Y.; Wang, J.; Yu, B.; Zhang, W.; Chen, J.; Qiao, J.; Zhang, J. A review of high temperature co-electrolysis of $\mathrm{H}_{2} \mathrm{O}$ and $\mathrm{CO}_{2}$ to produce sustainable fuels using solid oxide electrolysis cells (SOECs): Advanced materials and technology. Chem. Soc. Rev. 2017, 46, 1427-1463. [CrossRef]

8. Jacobsen, T.; Mogensen, M. The course of oxygen partial pressure and electric potentials across an oxide electrolyte cell. ECS Trans. 2008, 13, 259-273. [CrossRef]

9. Virkar, A.V. Mechanism of oxygen electrode delamination in solid oxide electrolyzer cells. Int. J. Hydrogen Energy 2010, 35, 9527-9543. [CrossRef]

10. Rashkeev, S.N.; Glazoff, M.V. Atomic-scale mechanisms of oxygen electrode delamination in solid oxide electrolyzer cells. Int. J. Hydrogen Energy 2012, 37, 1280-1291. [CrossRef]

11. Kim, J.; Ji, H.I.; Dasari, H.P.; Shin, D.; Song, H.; Lee, J.H.; Kim, B.K.; Je, H.J.; Lee, H.W.; Yoon, K.J. Degradation mechanism of electrolyte and air electrode in solid oxide electrolysis cells operating at high polarization. Int. J. Hydrogen Energy 2013, 38, 1225-1235. [CrossRef]

12. Graves, C.; Ebbesen, S.D.; Jensen, S.H.; Simonsen, S.B.; Mogensen, M.B. Eliminating degradation in solid oxide electrochemical cells by reversible operation. Nat. Mater. 2015, 14, 239-244. [CrossRef] [PubMed]

13. Chen, K.; Liu, S.S.; Ai, N.; Koyama, M.; Jiang, S.P. Why solid oxide cells can be reversibly operated in solid oxide electrolysis cell and fuel cell modes? Phys. Chem. Chem. Phys. 2015, 17, 31308-31315. [CrossRef] [PubMed]

14. Kawashima, T. Phase equilibria in $\mathrm{ZrO}_{2}-\mathrm{Y}_{2} \mathrm{O}_{3}-\mathrm{MnO}_{t}$ ternary system at $1673 \mathrm{~K}$. Mater. Trans. JIM 1999, 40, 967-971. [CrossRef]

15. Pavlyuchkov, D.; Savinykh, G.; Fabrichnaya, O. Experimental investigation and thermodynamic modeling of the $\mathrm{ZrO}_{2}-\mathrm{MnO}_{\mathrm{x}}$ system. J. Eur. Ceram. Soc. 2015, 35, 3623-3632. [CrossRef]

16. Stępień, J.; Sikora, M.; Kapusta, C.; Pomykalska, D.; Bućko, M. Determination of oxygen vacancy limit in Mn substituted yttria stabilized zirconia. J. Appl. Phys. 2018, 123, 185108. [CrossRef]

17. Kawashima, T.; Hishinuma, M. Phase transformation of yttria-stabilized zirconia $\left(3 \mathrm{~mol} \% \mathrm{Y}_{2} \mathrm{O}_{3}\right)$ in fuel cell caused by manganese diffusion. Mater. Trans. JIM 1998, 39, 617-620. [CrossRef]

18. Matraszek, A.; Miller, M.; Singheiser, L.; Hilpert, K. Thermodynamic vaporization studies of the manganese oxide-yttria stabilized zirconia (YSZ) solid solution. J. Eur. Ceram. Soc. 2004, 24, 2649-2656. [CrossRef]

19. Kawada, T.; Sakai, N.; Yokokawa, H.; Dokiya, M. Electrical properties of transition-metal-doped YSZ. Solid State Ionics 1992, 53-56, 418-425. [CrossRef]

20. Kawada, T.; Sakai, N.; Yokokawa, H.; Dokiya, M. Reaction between solid oxide fuel cell materials. Solid State Ionics 1992, 50, 189-196. [CrossRef]

21. Pomykalska, D.; Bućko, M.M.; Rękas, M. Electrical conductivity of $\mathrm{MnO}_{x}-\mathrm{Y}_{2} \mathrm{O}_{3}-\mathrm{ZrO}_{2}$ solid solutions. Solid State Ionics 2010, 181, 48-52. [CrossRef]

22. Huang, X.J.; Weppner, W. Characteristics of transition metal oxide doping of YSZ: Structure and electrical properties. J. Chem. Soc. Faraday Trans. 1996, 92, 2173-2178. [CrossRef]

23. Kim, J.H.; Choi, G.M. Mixed ionic and electronic conductivity of $\left[\left(\mathrm{ZrO}_{2}\right)_{0.92}\left(\mathrm{Y}_{2} \mathrm{O}_{3}\right)_{0.08}\right]_{1-y}\left(\mathrm{MnO}_{1.5}\right)_{y}$. Solid State Ionics 2000, 130, 157-168. [CrossRef]

24. Mahapatra, M.K.; Li, N.; Verma, A.; Singh, P. Electrical conductivity of manganese doped yttria (8 mol\%) stabilized zirconia. Solid State Ionics 2013, 253, 223-226. [CrossRef]

25. Slilaty, R.M.; Marques, F.M.B. Electrical conductivity of yttria stabilized zirconia (YSC) doped with transition metals. Bol. Soc. Esp. Cerám. Vidr. 1996, 35, 109-115.

26. Kim, J.H.; Choi, G.M. Electrical conductivity of zirconia-Mn oxide mixture. Mat. Res. Soc. Symp. Proc. 1999, 548, 611-616. [CrossRef]

27. Appel, C.C.; Bonanos, N.; Horsewell, A.; Linderoth, S. Ageing behaviour of zirconia stabilised by yttria and manganese oxide. J. Mater. Sci. 2001, 36, 4493-4501. [CrossRef] 
28. Zhang, T.S.; Chan, S.H.; Wang, W.; Hbaieb, K.; Kong, L.B.; Ma, J. Effect of Mn addition on the densification, grain growth and ionic conductivity of pure and $\mathrm{SiO}_{2}$-containing 8YSZ electrolytes. Solid State Ionics 2009, 180, 82-89. [CrossRef]

29. Kawashima, T. Electrical conductivity and defect structure of manganese oxide-doped yttria-stabilized zirconia $\left(3 \mathrm{~mol} \% \mathrm{Y}_{2} \mathrm{O}_{3}\right)$. Mater. Trans. JIM 1998, 39, 1115-1120. [CrossRef]

30. Li, N.; Keane, M.; Mahapatra, M.K.; Singh, P. Mitigation of the delamination of LSM anode in solid oxide electrolysis cells using manganese-modified YSZ. Int. J. Hydrogen Energy 2013, 38, 6298-6303. [CrossRef]

31. Li, N.; Asadikiya, M.; Zhong, Y.; Singh, P. Evolution of porous YSZ surface morphology in YSZ-MnO system. J. Am. Ceram. Soc. 2018, 101, 4802-4811. [CrossRef]

32. Gorelov, V.P. Transport number determinations in ionic conductors using EMF measurements with active load. Sov. Electrochem. 1988, 24, 1272-1274.

33. Kharton, V.V.; Yaremchenko, A.A.; Viskup, A.P.; Mather, G.C.; Naumovich, E.N.; Marques, F.M.B. Ionic and p-type electronic conduction in $\mathrm{LaGa}(\mathrm{Mg}, \mathrm{Nb}) \mathrm{O}_{3-\delta}$ perovskites. Solid State Ionics 2000, 128, 79-90. [CrossRef]

34. Pascual, M.J.; Kharton, V.V.; Tsipis, E.V.; Yaremchenko, A.A.; Lara, C.; Durán, A.; Frade, J.R. Transport properties of sealants for high-temperature electrochemical applications: $\mathrm{RO}-\mathrm{BaO}_{-} \mathrm{SiO}_{2}(\mathrm{R}=\mathrm{Mg}$, Zn) glass-ceramics. J. Eur. Ceram. Soc. 2006, 26, 3315-3324. [CrossRef]

35. Natoli, A.; Yaremchenko, A.; Frade, J.R. Structural design of 5 mol.\% yttria partially stabilized zirconia (5Y-PSZ) by addition of manganese oxide and direct firing. Ceramics 2020, 3, 345-358. [CrossRef]

36. Shannon, R.D. Revised effective ionic radii and systematic studies of interatomic distances in halides and chaleogenides. Acta Crystallogr. A 1976, 32, 751-767. [CrossRef]

37. Van Herle, J.; Vasquez, R. Conductivity of Mn and Ni-doped stabilized zirconia electrolyte. J. Eur. Ceram. Soc. 2004, 24, 1177-1180. [CrossRef]

38. Lybye, D.; Liu, Y.L.; Mogensen, M.; Linderoth, S. Effect of impurities on the conductivity of Sc and Y co-doped ZrO $\mathrm{Z}_{2}$. Electrochem. Soc. Proc. 2005, 2005, 954-963. [CrossRef]

39. Gao, L.; Zhou, L.; Li, C.; Feng, J.; Lu, Y. Kinetics of stabilized cubic zirconia formation from $\mathrm{MnO}_{2}-\mathrm{ZrO}_{2}$ diffusion couple. J. Mater. Sci. 2013, 48, 974-977. [CrossRef]

40. Srivastava, S.K.; Lejay, P.; Barbara, B.; Boisron, O.; Pailhes, S.; Bouzerar, G. Absence of ferromagnetism in Mn-doped tetragonal zirconia. J. Appl Phys. 2011, 110, 043929. [CrossRef]

41. Parmigiani, F.; Depero, L.E.; Sangaletti, L.; Samoggia, G. An XPS study of yttria-stabilised zirconia single crystals. J. Electron. Spectrosc. Relat. Phenom. 1993, 63, 1-10. [CrossRef]

42. Pomfret, M.B.; Stoltz, C.; Varughese, B.; Walker, R.A. Structural and compositional characterization of yttria-stabilized zirconia: Evidence of surface-stabilized, low-valence metal species. Anal. Chem. 2005, 77, 1791-1795. [CrossRef] [PubMed]

43. Oku, M.; Hirokawa, K.; Ikeda, S. X-ray photoelectron spectroscopy of manganese-Oxygen systems. J. Electron. Spectrosc. Relat. Phenom. 1975, 7, 465-473. [CrossRef]

44. Biesinger, M.C.; Payne, B.P.; Grosvenor, A.P.; Lau, L.W.; Gerson, A.R.; Smart, R.S.C. Resolving surface chemical states in XPS analysis of first row transition metals, oxides and hydroxides: Cr, Mn, Fe, Co and Ni. Appl. Surf. Sci. 2011, 257, 2717-2730. [CrossRef]

45. Junta, J.L.; Hochella, M.F., Jr. Manganese (II) oxidation at mineral surfaces: A microscopic and spectroscopic study. Geochim. Cosmochim. Acta 1994, 58, 4985-4999. [CrossRef]

46. Brundle, C.R.; Baker, A.D. (Eds.) Electron. Spectroscopy: Theory, Techniques and Applications; Academic Press: London, UK, 1977; Volume 1.

47. Grundy, A.N.; Hallstedt, B.; Gauckler, L.J. Assessment of the Mn-O system. J. Phase Equilib. 2003, 24, 21-39. [CrossRef]

48. Occhiuzzi, M.; Cordischi, D.; Dragone, R. Manganese ions in the monoclinic, tetragonal and cubic phases of zirconia: An XRD and EPR study. Phys. Chem. Chem. Phys. 2003, 5, 4938-4945. [CrossRef]

49. Sasaki, K.; Murugaraj, P.; Haseidl, M.; Maier, J. Redox-active impurity ions in solid electrolytes and their influence on transport properties. Electrochem. Soc. Proc. 1997, 97-40, 1190-1202. [CrossRef]

50. Sasaki, K.; Maier, J. In situ EPR studies of chemical diffusion in oxides. Phys. Chem. Chem. Phys. 2000, 2, 3055-3061. [CrossRef]

51. Chen, M.; Hallstech, B.; Gauckler, L.J. Thermodynamic modelling of phase equilibria in the Mn-Y-Zr-O system. Solid State Ionics 2005, 176, 1457-1464. [CrossRef]

52. Sasaki, K.; Claus, J.; Maier, J. Defect chemistry of oxides in partially frozen-in states: Case studies for $\mathrm{ZrO}_{2}\left(\mathrm{Y}_{2} \mathrm{O}_{3}\right), \mathrm{SrZrO}_{3}\left(\mathrm{Y}_{2} \mathrm{O}_{3}\right)$, and $\mathrm{SrTiO}_{3}$. Solid State Ionics 1999, 121, 51-60. [CrossRef]

53. Sasaki, K.; Maier, J. Re-analysis of defect equilibria and transport parameters in $\mathrm{Y}_{2} \mathrm{O}_{3}$-stabilized ZrO2 using EPR and optical relaxation. Solid State Ionics 2000, 134, 303-321. [CrossRef]

54. Appel, C.C.; Botton, G.A.; Horsewell, A.; Stobbs, W.M. Chemical and structural changes in manganese-doped yttria-stabilized zirconia studied by electron energy loss spectroscopy combined with electron diffraction. J. Am. Ceram. Soc. 1999, 82, 429-435. [CrossRef]

55. Kharton, V.V.; Marques, F.M.B. Interfacial effects in electrochemical cells for oxygen ionic conduction measurements. I. The e.m.f. method. Solid State Ionics 2001, 140, 381-394. [CrossRef]

56. Frade, J.R.; Kharton, V.V.; Yaremchenko, A.A.; Tsipis, E.V. Applicability of emf measurements under external load resistance conditions for ion transport number determination. J. Solid State Electrochem. 2006, 10, 96-103. [CrossRef] 
57. Park, J.H.; Blumenthal, R.N. Electronic transport in 8 mole percent $\mathrm{Y}_{2} \mathrm{O}_{3}-\mathrm{ZrO}_{2}$. J. Electrochem. Soc. 1989, 136, 2867-2876. [CrossRef]

58. Mori, M.; Abe, T.; Itoh, H.; Yamamoto, O.; Takeda, Y.; Kawahara, T. Cubic-stabilized zirconia and alumina composites as electrolytes in planar type solid oxide fuel cells. Solid State Ionics 1994, 74, 157-164. [CrossRef]

59. Tsipis, E.V.; Kharton, V.V. Electrode materials and reaction mechanisms in solid oxide fuel cells: A brief review I. Performancedetermining factors. J. Solid State Electrochem. 2008, 12, 1039-1060. [CrossRef]

60. Liu, T.; Zhang, X.; Wang, X.; Yu, J.; Li, L. A review of zirconia-based solid electrolytes. Ionics 2016, 22, 2249-2262. [CrossRef]

61. Yamamoto, O.; Arachi, Y.; Sakai, H.; Takeda, Y.; Imanishi, N.; Mizutani, Y.; Kawai, M.; Nakamura, Y. Zirconia based oxide ion conductors for solid oxide fuel cells. Ionics 1998, 4, 403-408. [CrossRef]

62. Appel, C.C. Zirconia stabilized by Y and Mn: A microstructural characterization. Ionics 1995, 1, 406-413. [CrossRef]

63. Khan, M.S.; Islam, M.S.; Bates, D.R. Cation doping and oxygen diffusion in zirconia: A combined atomistic simulation and molecular dynamics study. J. Mater. Chem. 1998, 8, 2299-2307. [CrossRef]

64. Marrocchelli, D.; Perry, N.H.; Bishop, S.R. Understanding chemical expansion in perovskite-structured oxides. Phys. Chem. Chem. Phys. 2015, 17, 10028-10039. [CrossRef] [PubMed]

65. Frade, J.R. Challenges imposed by thermochemical expansion of solid state electrochemical materials. In Solid Oxide Fuels Cells: Facts and Figures; Irvine, J.T.S., Connor., P., Eds.; Springer: London, UK, 2013; pp. 95-119.

66. Yaremchenko, A.A.; Mikhalev, S.M.; Kravchenko, E.S.; Frade, J.R. Thermochemical expansion of mixed-conducting (Ba,Sr)Co0.8Fe0.2O3- $\delta$ ceramics. J. Eur. Ceram. Soc. 2014, 34, 703-715. [CrossRef]

67. Tietz, F. Thermal Expansion of SOFC Materials. Ionics 1999, 5, 129-139. [CrossRef]

68. Jiang, S.P. Development of lanthanum strontium manganite perovskite cathode materials of solid oxide fuel cells: A review. J. Mater. Sci. 2008, 43, 6799-6833. [CrossRef]

69. Sun, C.; Hui, R.; Roller, J. Cathode materials for solid oxide fuel cells: A review. J. Solid State Electrochem. 2010, 14, 1125-1144. [CrossRef]

70. Naumovich, E.N.; Zakharchuk, K.; Obrębowski, S.; Yaremchenko, A. (La,Sr)(Fe,Co) $\mathrm{O}_{3}$-based cathode contact materials for intermediate-temperature solid oxide fuel cells. Int. J. Hydrogen Energy 2017, 42, 29443-29453. [CrossRef]

71. Tarutin, A.P.; Lyagaeva, J.G.; Medvedev, D.A.; Bi, L.; Yaremchenko, A.A. Recent advances in layered $\mathrm{Ln}_{2} \mathrm{NiO}_{4+\delta}$ nickelates: Fundamentals and prospects of their applications in protonic ceramic fuel and electrolysis cells. J. Mater. Chem. A 2021, 9, 154-195. [CrossRef]

72. Yaremchenko, A.A.; Kharton, V.V.; Kolotygin, V.A.; Patrakeev, M.V.; Tsipis, E.V.; Waerenborgh, J.C. Mixed conductivity, thermochemical expansion and electrochemical activity of Fe-substituted $(\mathrm{La}, \mathrm{Sr})(\mathrm{Cr}, \mathrm{Mg}) \mathrm{O}_{3-\delta}$ for solid oxide fuel cell anodes. J. Power Sources 2014, 249, 483-496. [CrossRef]

73. Yaremchenko, A.A.; Macías, J.; Kovalevsky, A.V.; Arias-Serrano, B.I.; Frade, J.R. Electrical conductivity and thermal expansion of Ln-substituted $\mathrm{SrTiO}_{3}$ for solid oxide cell electrodes and interconnects: The effect of rare-earth cation size. J. Power Sources 2020, 474, 228531. [CrossRef]

74. Yasuda, I.; Hishinuma, M. Electrical conductivity, dimensional instability and internal stresses of $\mathrm{CeO}_{2}-\mathrm{Gd}_{2} \mathrm{O}_{3}$ solid solutions. Electrochem. Soc. Proc. 1998, 97, 178-187.

75. Wang, S.; Katsuki, M.; Hashimoto, T.; Dokiya, M. Expansion behavior of $\mathrm{Ce}_{1-\mathrm{y}} \mathrm{Gd}_{\mathrm{y}} \mathrm{O}_{2.0-0.5 y-\delta}$ under various oxygen partial pressures evaluated by HTXRD. J. Electrochem. Soc. 2003, 150, A952-A958. [CrossRef] 